\title{
Novel photosensitizer for dye-sensitized solar cell based on ionic liquid-doped blend polymer electrolyte
}

\author{
Dheeraj Devadiga $^{1}$ - M. Selvakumar ${ }^{1}$ (1) $\cdot$ Prakasha Shetty $^{1}$ - M. G. Mahesha ${ }^{2} \cdot$ Deepak Devadiga $^{3} \cdot$ T. N. Ahipa ${ }^{3} \cdot$ \\ S. Senthil Kumar ${ }^{4}$
}

Received: 30 May 2020 / Revised: 8 February 2021 / Accepted: 13 February 2021 / Published online: 2 March 2021

(C) The Author(s) 2021

\begin{abstract}
The existing energy situation demands not only the huge energy in a short time but also clean energy. In this regard, an integrated photo-supercapacitor device has been fabricated in which photoelectric conversion and energy storage are achieved simultaneously. A novel carbazole-based dye is synthesized and characterized for photosensitizer. The silver-doped titanium dioxide $\left(\mathrm{Ag}^{-\mathrm{TiO}_{2}}\right)$ is synthesized, and it is used as photoanode material. Different concentrations of tetrabutylammonium iodide (TBAI)-doped polyvinyl alcohol-polyvinylpyrrolidone (PVA-PVP) blend polymer electrolytes are prepared, and their conductivity and dielectric properties were studied. Reduced graphene oxide (r-GO) is synthesized by a one-pot synthesis method and confirmed using Raman spectroscopy for counter electrode material in dye-sensitized solar cell (DSSC) and supercapacitor electrodes. The $\mathrm{DSSC}$ having $4 \% \mathrm{Ag}^{-\mathrm{TiO}} \mathrm{O}_{2}$-based photoanode showed the highest efficiency of 1.06\% (among r-GO counter electrodes) and 2.37\% (among platinum counter electrodes). The supercapacitor before integration and after integration exhibits specific capacitance of $1.72 \mathrm{Fg}^{-1}$ and $1.327 \mathrm{Fg}^{-1}$, respectively.
\end{abstract}

Keywords Dye-sensitized solar cell $\cdot$ Supercapacitor $\cdot$ Silver doped titanium dioxide $\cdot$ Carbazole based dye $\cdot$ Blend polymer electrolyte $\cdot$ Reduced graphene oxide

\section{Introduction}

As a result of the energy crisis, demand for renewable energy resources has become critical and, in particular, the use of

Highlights

- Novel D- $\pi-\mathrm{A}$ carbazole-based dye was synthesized.

- $\mathrm{TiO}_{2}$ and $2 \%, 4 \%$ and $6 \% \mathrm{Ag}$-doped $\mathrm{TiO}_{2}$ were synthesized using a modified sol-gel method.

- Polyvinyl alcohol-polyvinylpyrrolidone (PVA-PVP) blend polymer electrolytes doped with different concentrations of tetrabutylammonium iodide were prepared.

- Reduced graphene oxide was synthesized from graphite by one-pot synthesis method.

- Using CaBa dye, dye-sensitized solar cells were fabricated and integrated with supercapacitor.

M. Selvakumar

chemselva78@gmail.com

1 Department of Chemistry, Manipal Institute of Technology, Manipal Academy of Higher Education, Manipal, Karnataka 576104, India

2 Department of Physics, Manipal Institute of Technology, Manipal Academy of Higher Education, Manipal, Karnataka 576104, India solar energy is gaining supreme interest due to its abundant availability in nature [1]. Solar cells can be used to transform solar energy into electric energy. While dominant on the commercial market, the efficiency of silicon-based solar cells
3 Centre for Nano and Material Sciences, Jain University, Jain Global Campus, Jakkasandra Post, Ramanagara District, Bangalore 562112, India

4 Electrodics and Electrocatalysis Division, CSIR-Central Electrochemical Research Institute, Karaikudi 630003, India 
entails some environmental problems since it produces harmful chemicals such as silicon tetrachloride and trichlorosilane. Scientists have therefore focused on hybrid solar cells that are typical of low material costs and simple manufacturing processes. Presently, dye-sensitized solar cells (DSSCs) have gained considerable attention among hybrid solar cells because of their advantages like low cost of production, long life, low light performance, variety, mechanical robustness and flexible product integration [2, 3].

In the DSSC, the sensitizer plays a pivotal role because it initiates the electrical current by absorbing visible light in the solar cell [4]. Until the date, the state-of-the-art DSSCs are based on single sensitizers such as ruthenium dyes [5] and porphyrin dyes [6, 7] which have reached maximum photoconversion efficiency (PCE) under standard illumination. Metal-based sensitizers have few drawbacks for real application in DSSCs, including rareness, difficulty in purifying, environmental hazards and low molar extinction coefficients [5]. Because of their low toxicity, high structural versatility, being environmentally friendly, lower molar extinction coefficients and facile synthesis, metal-free organic sensitizers have drawn attention over metal-based organic sensitizers [4, 8].

Typically, metal-free organic sensitizers are in donor- $\pi-$ acceptor structure because this structure can produce intramolecular charge transfer (ICT) from donor to acceptor, improve light-harvesting capabilities and broaden the sensitizer absorption spectrum [9]. Different chromophores with different steric and electronic characters are used as electron donors, such as carbazole [10], phenothiazine [11], coumarin [12], indoline [13] and triarylamine [14]. In order to enhance the ability of light harvesting and to help intramolecular charge transfer, $\pi$ bridges are incorporated. Among these donors, carbazole is widely used for its electron-rich properties, good hole transport capability as well as very good chemical and thermal stability [15]. Not only the donor group but also the anchoring group play an important role in the performance of the DSSC. With the help of the anchoring groups, the sensitizer covalently bonded to the $\mathrm{TiO}_{2}$ surface shows a strong coupling and good stability of the device [16]. In most of the sensitizers, carboxylic acids $(\mathrm{COOH})$ are commonly used as an acceptor unit due to their good adherence to the semiconductor layer. The electron injection is carried out through this adhesion, which is the main mechanism that begins the electrical circuit in the DSSC. The conductive band of the semiconductor is positively shifted after sensitizing adsorption due to the deprotonation of the $\mathrm{COOH}$ acceptor group, resulting in an opencircuit photovoltage $\left(V_{\mathrm{OC}}\right)$ loss [17].

Solar conversion efficiency relies on open-circuit voltage $\left(V_{\mathrm{OC}}\right)$, photocurrent density $\left(J_{\mathrm{SC}}\right)$ and fill factor $(\mathrm{FF})$ of the DSSCs. The $J_{\mathrm{SC}}$ and FF are based on the adsorption and charge transport of dye molecules. Therefore, in order to enhance the photovoltaic properties of $\mathrm{TiO}_{2}$, it is important to increase its surface area, the effect of light harvesting, the adsorption activity of dye molecule and the charge transport. The doping method has been widely used to synthesize anode materials to improve the charge transfer capability and increase the $V_{\text {OC }}$ [18]. There are many studies in which silverdoped $\mathrm{TiO}_{2}$ was used as a anode material for DSSC applications because Ag doping increases dye adsorption and surface area and enhances interfacial charge transfer [19-21].

Liquid electrolyte-based DSSCs have many drawbacks, such as evaporation of the solvent, electrode degradation, degradation of the attached dye and difficulty in sealing the cell, which leads to lower cell life span [22]. Polymer electrolytes are used to address these drawbacks with volatile liquid electrolytes. It increases the long-term reliability of DSSCs and reduces issues such as sealing, electrode corrosion and leaking [23]. Some of the ion salts widely used in electrolytes are quaternary ammonium salts. The quaternary ammonium salts also produce cations instead of iodide ions. Reports show that cations have an effect on the transport rate, the strength of the sensitizing surface attachment and the oxidation rate of iodide that may affect the performance of solar cells [24].

In DSSCs, the counter electrode also plays a vital role in collecting electrons from the external circuit and transfers them to the cell, transmitting unabsorbed light back to the cell, which increases the use of sunlight. Most materials are used as counter electrodes, such as metal counter electrodes, carbon counter electrodes, polymer counter electrodes and hybrid counter electrodes [25]. Carbon-based materials such as graphene sheets, amorphous carbon and carbon nanotubes have favourable properties as Pt-free counter electrodes. Graphene is best known, among other carbon materials, for its excellent mechanical, optical, thermal and electrical properties [26-28].

The electrical energy generated in DSSC from sunlight cannot be stored directly. Henceforth, there is a demand for emergence of suitable energy storage technologies. The lightweight, small-sized, high-reliable and high-power density energy systems can be obtained by operating integrated power pack, energy harvesting and storage technologies together. In this regard, the development of integrated energy harvesting and storage technologies is required, which captures sunlight and converts into solar energy and simultaneously stores electrical energy. In recent years, the solar rechargeable supercapacitors (SCs) have been developed for the effective use of solar energy by integrating the solar cells and SCs [29].

In this work, we synthesized novel carbazole-based dye for photosensitizer and prepared different concentrations of Agdoped $\mathrm{TiO}_{2}$ nanoparticles for photoanode. The reduced graphene oxide was prepared for counter electrode and tetrabutylammonium iodide (TBAI) ionic liquid-doped polyvinyl alcohol-polyvinylpyrrolidone (PVA-PVP) blend polymer electrolyte used for the fabrication of hybrid supercapacitor. The integrated hybrid device structure is shown in Fig. 1. 


\section{Experimental}

\section{Materials and methods of preparation}

All chemicals and reagents were purchased from Merck, TCI and Sigma-Aldrich and used without any further purification. The FTIR spectra are recorded in $\mathrm{KBr}$ pellet using a Shimadzu $8400 \mathrm{~S}$ spectrometer in the range $400-4000 \mathrm{~cm}^{-1}$. ${ }^{1} \mathrm{H}-\mathrm{NMR}$ and ${ }^{13} \mathrm{C}$-NMR spectra are recorded in Bruker $(400 \mathrm{MHz}$ and $100 \mathrm{MHz}$, respectively) spectrometers with TMS as an internal reference. The X-ray diffraction (XRD) was recorded in Bruker Miniflex 600 model. All the electrochemical measurements were carried out using BioLogic SP- 150 . The $I-V$ characterizations of fabricated DSSCs were carried out using a Keithley 2450 source meter.

\section{Synthesis of substituted 4-(3-(9-ethyl-9H-carbazol-3- yl)acryloyl)benzoic acid}

Ethyl-9H-carbazole-3-carbaldehyde (1 equivalent) was added to the stirred mixture of 4-acetylbenzoic acid (1 equivalent) in ethanol, followed by $10 \% \mathrm{NaOH}$. The reaction mixture was agitated for $24 \mathrm{~h}$ at room temperature (RT) (Scheme 1). The precipitate obtained was filtered, washed with water and ethanol, dried and recrystallized using methanol to afford the desired product with $77 \%$ yield. M.P. $=220{ }^{\circ} \mathrm{C}$, FTIR $\left(\mathrm{cm}^{-1}\right)$ : $1581.08(\mathrm{C}=\mathrm{C}), 1654.42(-\mathrm{C}=\mathrm{C}-\mathrm{C}=\mathrm{O}), 1681.29(-$ $\mathrm{C}=\mathrm{O}), 2984.4(\mathrm{CH}), 3454.33(\mathrm{OH}) ;{ }^{1} \mathrm{H}$ NMR $(\mathrm{DMSO}) \delta$ (ppm): 1.35 (t, $J=7.1 \mathrm{~Hz}, 3 H), 4.50(\mathrm{q}, J=7.1 \mathrm{~Hz}, 2 H)$, $7.29(\mathrm{t}, J=7.5 \mathrm{~Hz}, 1 H), 7.52(\mathrm{t}, J=7.7 \mathrm{~Hz}, 1 H), 7.69(\mathrm{dd}, J$ $=16.2,8.4 \mathrm{~Hz}, 2 H), 8.03(\mathrm{~d}, J=22.5 \mathrm{~Hz}, 3 H), 8.12(\mathrm{~d}, J=8.1$ $\mathrm{Hz}, 2 H), 8.26(\mathrm{dd}, J=12.5,7.9 \mathrm{~Hz}, 3 H), 8.78(\mathrm{~s}, 1 H) ;{ }^{13} \mathrm{C}$ NMR (DMSO) $\delta$ (ppm): 14.24, 37.69, 110.08 (2C), 119.20, 120.07, 121.14, 122.69, 122.75, 123.19, 126.04 (2C), 126.67, 127.67, 128.74 (2C), 129.92 (2C), 140.59, 140.91, 141.67,
146.81, 167.75, 189.21; ESI-MS (m/z): $[\mathrm{M}]^{+}$calculated for $\mathrm{C}_{24} \mathrm{H}_{19} \mathrm{NO}_{3}: 369.42$, found: 370.0244 .

\section{Synthesis of pristine and silver-doped titanium dioxide}

$\mathrm{TiO}_{2}$ and silver-doped titanium dioxide $\left(\mathrm{Ag}-\mathrm{TiO}_{2}\right)$ nanoparticles were synthesized by a modified sol-gel route [30]. The procedures are as follows: to the stirred solution of acetic acid, titanium tetraisopropoxide (TTIP) was added followed by slow addition of water. (The TTIP, acetic acid and water are taken in 0.1:1:10 molar ratios). Then, the mixture was agitated for $6 \mathrm{~h}$ to achieve a clear translucent solution and it was finally dried at $90{ }^{\circ} \mathrm{C}$. The dried sample was calcinated for $2 \mathrm{~h}$ at 600 ${ }^{\circ} \mathrm{C}$. In order to prepare $\mathrm{Ag}-\mathrm{TiO}_{2}$, silver nitrate $(2 \mathrm{~mol} \%$, $4 \mathrm{~mol} \%$ and $6 \mathrm{~mol} \%$ ) in water was added to the mixture of titanium isopropoxide.

\section{Preparation of PVA-PVP blend polymer electrolytes}

PVA and PVP (1:1) are dispersed in DMSO under continuous stirring. After homogeneous solution formation, different weight percentages (10 to $50 \mathrm{wt} \%$ ) of TBAI was added followed by the addition of $\mathrm{I}_{2}$ into the polymer solution (one-tenth of the molar ratio of TBAI). The mixture was stirred until the solution become homogenous. The resultant polymer solution was poured over a Petri dish (Teflon) and dried overnight at $90^{\circ} \mathrm{C}$ in a vacuum oven to aid in the evaporation of solvents.

\section{Preparation of reduced graphene oxide}

A mixture of $13.3 \mathrm{~mL}$ of $\mathrm{H}_{3} \mathrm{PO}_{4}$ and $120 \mathrm{~mL}$ of concentrated $\mathrm{H}_{2} \mathrm{SO}_{4}$ (1:9 ratio) was added slowly to a mixture of $6 \mathrm{~g}$ of $\mathrm{KMnO}_{4}$ and $1 \mathrm{~g}$ graphite powder (6:1 weight equivalent). The mixture was then agitated for $24 \mathrm{~h}$ at $120^{\circ} \mathrm{C}$. Then, it was

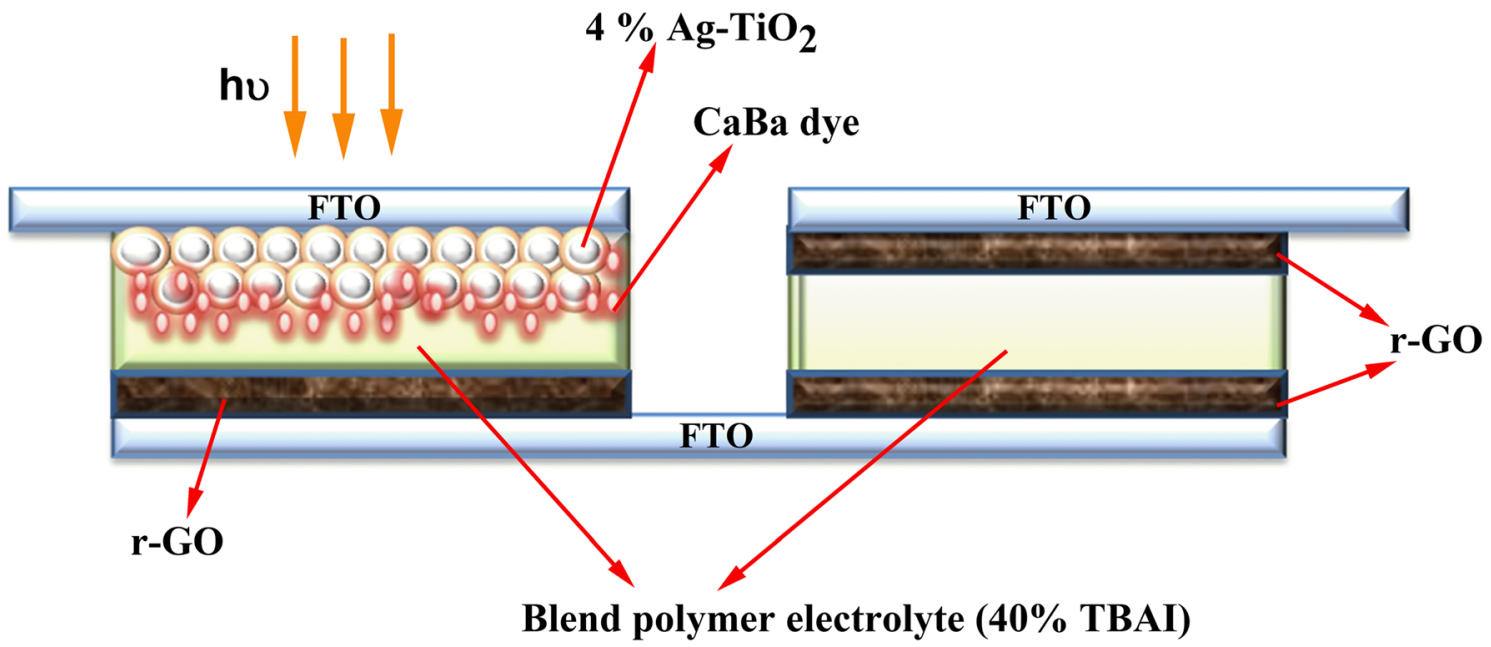

Fig. 1 Schematic illustration of an integrated device (DSSC-SC) 
Scheme 1 Synthesis of $\mathrm{CaBa}$ dye

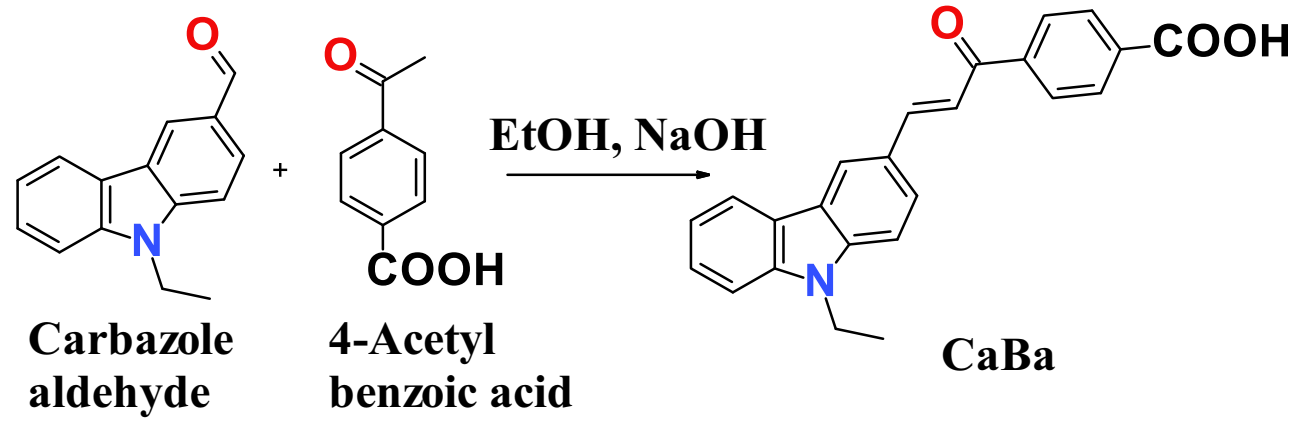

cooled to RT and poured into ice with $2 \mathrm{~mL} 30 \% \mathrm{H}_{2} \mathrm{O}_{2}$. A black precipitate with a clear supernatant solution was obtained [31]. The precipitate was purified by water washing in continuous ultracentrifugation followed by vacuum filtration. To extract excess water from the samples and ensure fast drying at RT, acetone has been added to the sample. After drying, solid samples were made ready for characterization.

\section{Fabrication of DSSC}

Fluorine-doped tin oxide (FTO)-coated glass substrates were cleaned using detergent, water, acetone and isopropyl alcohol, respectively. After cleaning, substrates were immersed in $40 \mathrm{mM}$ titanium tetrachloride for $45 \mathrm{~min}$ at $70{ }^{\circ} \mathrm{C}$ to form a blocking layer. The $\mathrm{TiO}_{2}$ or $\mathrm{Ag}-\mathrm{TiO}_{2}$ layer was coated by doctor blade technique using water, acetyl acetone and hydroxypropyl cellulose mixture. The substrates were then placed for sintering for $30 \mathrm{~min}$ at $450{ }^{\circ} \mathrm{C}$. Then, substrates were dipped in $0.5 \mathrm{mM}$ methanol solution of synthesized 4-(3-(9-ethyl-9H-carbazol-3-yl)acryloyl)benzoic acid (CaBa) dye for $24 \mathrm{~h}$ at RT. Counter electrodes were prepared by coating prepared reduced graphene oxide ( $\mathrm{r}-\mathrm{GO})$ on the FTO substrate. Then, prepared high conductive blend polymer electrolyte was sandwiched between two electrodes.

\section{Fabrication of SC-integrated DSSC}

The integrated device was fabricated as shown in Fig. 1. On the common platform of $\mathrm{r}-\mathrm{GO}$, counter electrode in $\mathrm{SC}$ cell was fabricated using r-GO as positive and negative electrodes with prepared blend polymer electrolyte film sandwiched between them.

\section{Characterization techniques}

$\mathrm{TiO}_{2}$ and $4 \% \mathrm{Ag}-\mathrm{TiO}_{2}$ were coated on FTO substrate to measure cyclic voltammograms (CVs) of the material. $\mathrm{CV}$ was recorded in a three-electrode system having an aqueous $0.5 \mathrm{M} \mathrm{KOH}$ solution. To investigate electrochemical impedance spectroscopy (EIS) and the Tafel polarization curve, the dummy cells were fabricated with two identical electrodes having $\mathrm{TiO}_{2}$ or $4 \%$ Ag- $\mathrm{TiO}_{2}$ material and separated by $40 \%$
TBAI electrolyte film. The EIS measurements were carried out within the frequency of $100 \mathrm{mHz}-1 \mathrm{MHz}$. Different concentrations of TBAI-doped blend polymer electrolyte film were placed between the copper electrodes having an area of $1 \mathrm{~cm}^{2}$. Paper clips were used for good connectivity between the electrodes and electrolyte. The conductivity, impedance and dielectric characteristics have been studied using EIS. The measurements of the EIS were carried out at $100 \mathrm{mHz}-$ $1 \mathrm{MHz}$ frequency. $\mathrm{r}-\mathrm{GO}$ and Pt were coated on FTO substrate to measure the $\mathrm{CV}$ of the material. $\mathrm{CV}$ was recorded in a threeelectrode system having a liquid electrolyte (KI and $\mathrm{I}_{2}$ in acetonitrile). To investigate EIS, the dummy cells were fabricated having two r-GO or Pt identical electrodes and separated by $40 \%$ TBAI electrolyte film and experiments were carried out within the frequency of $100 \mathrm{mHz}-1 \mathrm{MHz}$. Further, the Tafel polarization curves were also analysed using the symmetric cells. The $I-V$ characterizations of fabricated DSSCs were carried out under air mass (AM) 1.5 condition using Keithley 2450 source meter, and EIS measurements of fabricated devices were carried out at $100 \mathrm{mHz}-1 \mathrm{MHz}$ frequency.

\section{Results and discussion}

\section{Optical properties of $\mathrm{CaBa}$}

The ultraviolet-visible (UV-vis) absorption spectrum of a $\mathrm{CaBa}$ dye in tetrahydrofuran (THF) solution is shown in Fig. 2a. The $\mathrm{CaBa}$ dye shows three distinct bands of absorption: one band at $289.6 \mathrm{~nm}$ corresponding to the $\pi-\pi^{*}$ electron transitions of the conjugated molecules, the another band at $394 \mathrm{~nm}$ which can be attributed to an ICT between the carbazole-donating unit with the anchor group and the third band which is in between these two bands which arises due to the highest occupied molecular orbital (HOMO) $-1 \rightarrow$ lowest unoccupied molecular orbital (LUMO) or HOMO $\rightarrow$ LUMO +1 transition [32].

The UV-vis spectrum of $\mathrm{CaBa}$ dye-coated $\mathrm{TiO}_{2}$ is displayed in Fig. 2b in which broadened absorption of $\mathrm{CaBa}$ dye was observed after anchoring to the $\mathrm{TiO}_{2}$ surface and the onset of absorption got redshifted to more than $30 \mathrm{~nm}$. This is because of the deprotonation of the acid group present in 

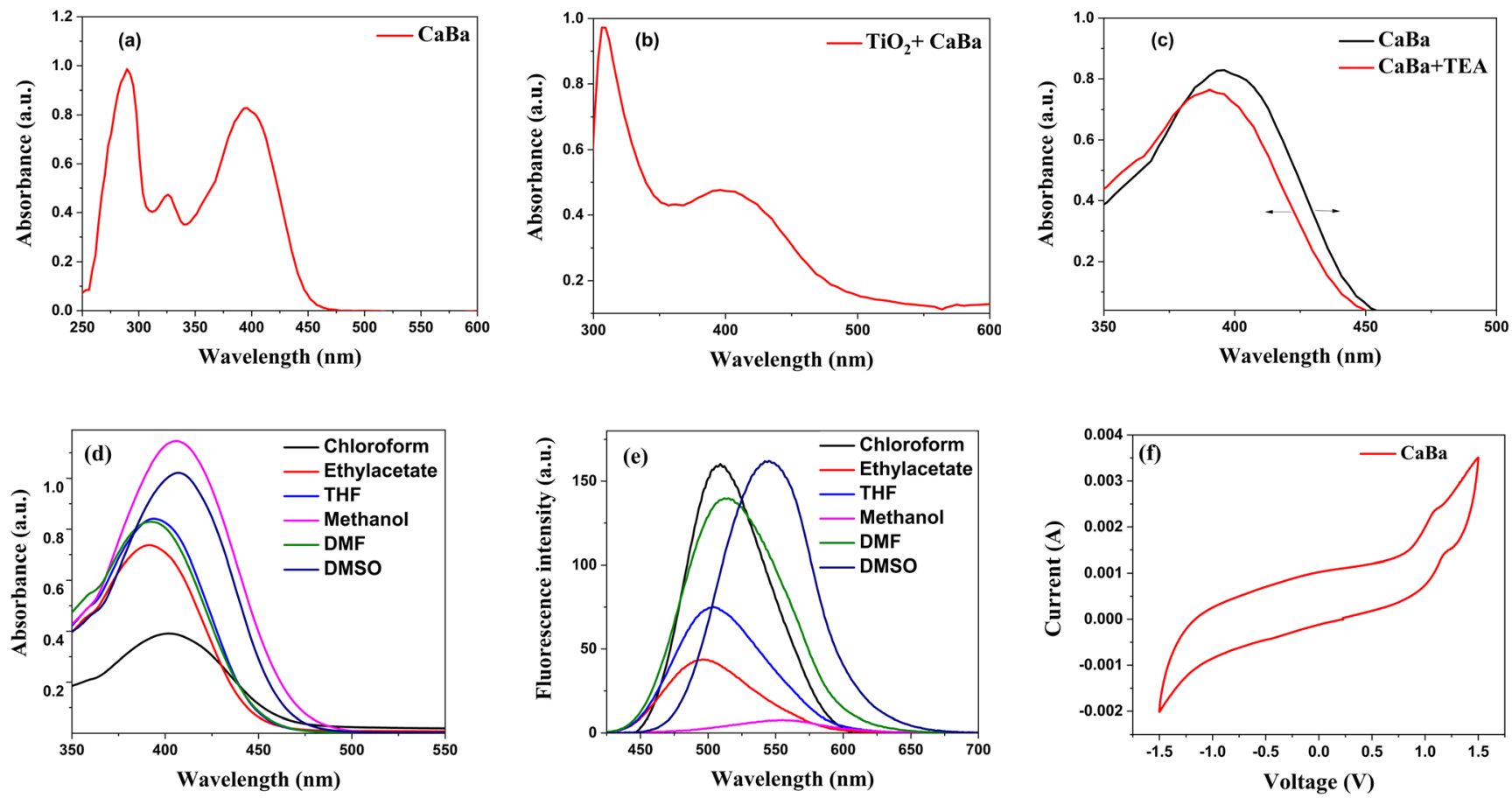

Fig. 2 a UV-visible spectra of CaBa dye in $\operatorname{THF}\left(10^{-5} \mathrm{M}\right)$. b UV-visible spectra of $\mathrm{CaBa}$ dye coated on $\mathrm{TiO}_{2}$ film. $\mathbf{c}$ UV-visible spectra of $\mathrm{CaBa}$ dye in THF in the presence of TEA. d UV-visible spectra of CaBa dye in

different solvents. e Fluorescence spectra of $\mathrm{CaBa}$ dye in different solvents. f Cyclic voltammogram of $\mathrm{CaBa}$ dye

$\mathrm{CaBa}$ dye and the charge transfer $(\mathrm{CT})$ transitions of the $\mathrm{CaBa}$ dye anchored on $\mathrm{TiO}_{2}$. The UV-vis spectra of $\mathrm{CaBa}$ dye taken in THF solvent in the presence of triethylamine (TEA) to understand CT transitions are shown in Fig. 2c. Due to the deprotonation, $\mathrm{CaBa}$ dye showed blueshift and it suggests in the presence of TEA, acceptor capacity was reduced, whereas the redshift in the absorption spectra of the $\mathrm{CaBa}$ dye-bound $\mathrm{TiO}_{2}$ film suggests the $J$-aggregation of a dye [33]. Aggregation usually results in a loss of exciton due to recombination, but many literature studies also suggest the effect of $J$-aggregation which contributes to better light-harvesting capacity which, in turn, leads to enhanced device efficiency [1, 34, 35].

\section{Effect of solvents on absorption and emission spectra of $\mathrm{CaBa}$ dye}

The absorption and emission spectra of $\mathrm{CaBa}$ dye were measured at $1 \times 10^{-5} \mathrm{M}$ concentration in different solvents with different polarity levels, and obtained results are depicted in Fig. 2d and e. Figure S5 depicts the solvent effect on $\mathrm{CaBa}$ dye under visible light (normal light), short UV and long UV illumination. The $\mathrm{CaBa}$ dye exhibited a broad absorption band, suggesting that the allowed transition of $\pi-\pi^{*}$ with charge transfer character [36]. The calculated values of absorption maximum, emission maximum, optical band gap and CIE coordinates of $\mathrm{CaBa}$ dye in different solvents are given in Table $\mathrm{S} 1$. Absorption spectra of $\mathrm{CaBa}$ dye showed a minimal difference in absorption maxima going from nonpolar solvents to polar solvents. A redshift of $16 \mathrm{~nm}$ was seen in the absorption maxima of $\mathrm{CaBa}$ dye going from non-polar solvents to polar solvents. The emission spectra of $\mathrm{CaBa}$ dye in different solvents were recorded under their respective excitation wavelengths, and obtained spectra are shown in Fig. 2e. The $\mathrm{CaBa}$ dye showed different emission bands as the polarity changes (496 to $555 \mathrm{~nm}$ ). The emission spectrum was not much changed in aprotic solvents except DMSO due to its high dielectric constant/high polarity of the solvent; however a significant redshift of $59 \mathrm{~nm}$ is seen in protic solvent (i.e. methanol solvent), which can be attributed to the hydrogen bond formation between the acid functionality of the dye $\mathrm{CaBa}$ and the solvent. This result suggests that involvement of photo-induced ICT in the singlet-excited state from the electron-donating to electron-accepting group with larger dipole moment in the excited state than in the ground state [37]. The fluorescence intensity of $\mathrm{CaBa}$ dye in methanol was comparatively of lesser intensity when compared to the intensities of $\mathrm{CaBa}$ dye in aprotic polar solvents. The reason for these different solvent effects on fluorescence intensity may be due to the effect of hydrogen bond on the radiationless deactivation process [38]. Further, luminance parameters of $\mathrm{CaBa}$ dye in different solvents were characterized by the CIE system with two colour coordinates ( $x$ and $y$ ) under long UV illumination. From the CIE coordinate diagram (Fig. S6), it is noted that, when the dye $\mathrm{CaBa}$ is dissolved in solvents such as chloroform, ethyl acetate, THF and DMF, it emits the 
colour in bluish green region under long UV illumination, whereas, when it is dissolved in the highly polar DMSO and protic methanol solvents, it exhibits the colour in the greenish yellow region under long UV illumination.

\section{Electrochemical properties of $\mathrm{CaBa}$ dye}

To determine electrode potential and HOMO and LUMO energy levels of $\mathrm{CaBa}$ dye, cyclic voltammetry $(\mathrm{CV})$ was performed in acetonitrile solution containing $0.1 \mathrm{~N} \mathrm{TEABF}_{4}$ at a scan rate of $20 \mathrm{mV} \mathrm{s}^{-1}$. These values are useful to determine the thermodynamic feasibility of electron injection from the HOMO level of dye molecule into the metal oxide conduction band and electrolyte dye regeneration. Figure $2 \mathrm{f}$ depicts the cyclic voltammogram of $\mathrm{CaBa}$ dye. $\mathrm{CaBa}$ dye showed first oxidation potential corresponding to $\mathrm{HOMO}$ versus NHE at $1.08 \mathrm{~V}$ (Table 1 ) which is more positive than the redox potential of iodine/iodide electrolyte ( $0.4 \mathrm{~V}$ vs. NHE), indicating the regeneration of the oxidized dye ground state by accepting an electron from electrolyte [39]. The excited-state oxidation potential, i.e. LUMO energy level of the dye, was calculated from the equation $E_{\mathrm{LUMO}}=E_{\mathrm{HOMO}}-E_{0-0}$ and was found to be $-1.69 \mathrm{~V}$ versus NHE. The LUMO is more negative than the conduction band of $\mathrm{TiO}_{2}(-0.5 \mathrm{~V}$ vs. NHE), and it indicates that injection of photogenerated electrons into the conduction band of $\mathrm{TiO}_{2}$ is energetically permitted [40]. From these values, we can evidently deduce that $\mathrm{CaBa}$ dye could be used as a sensitizer in DSSC.

\section{XRD analysis of $\mathrm{TiO}_{2}$ and $\mathrm{Ag}$-doped $\mathrm{TiO}_{2}$}

The XRD patterns of synthesized $\mathrm{TiO}_{2}$ and $\mathrm{Ag}-\mathrm{TiO}_{2}$ nanoparticles are shown in Fig. 3. All the diffraction peaks of the $\mathrm{TiO}_{2}$ and $\mathrm{Ag}-\mathrm{TiO}_{2}$ nanoparticles could be indexed to the anatase crystalline phase of $\mathrm{TiO}_{2}$ (space group I41/amd, card no. 211276 in the JCPDS database). The intense and sharp peaks near $25.4^{\circ}, 37.9^{\circ}, 48.1^{\circ}$ and $54^{\circ}$ correspond to diffraction planes such as (101), (004), (200) and (211), respectively.

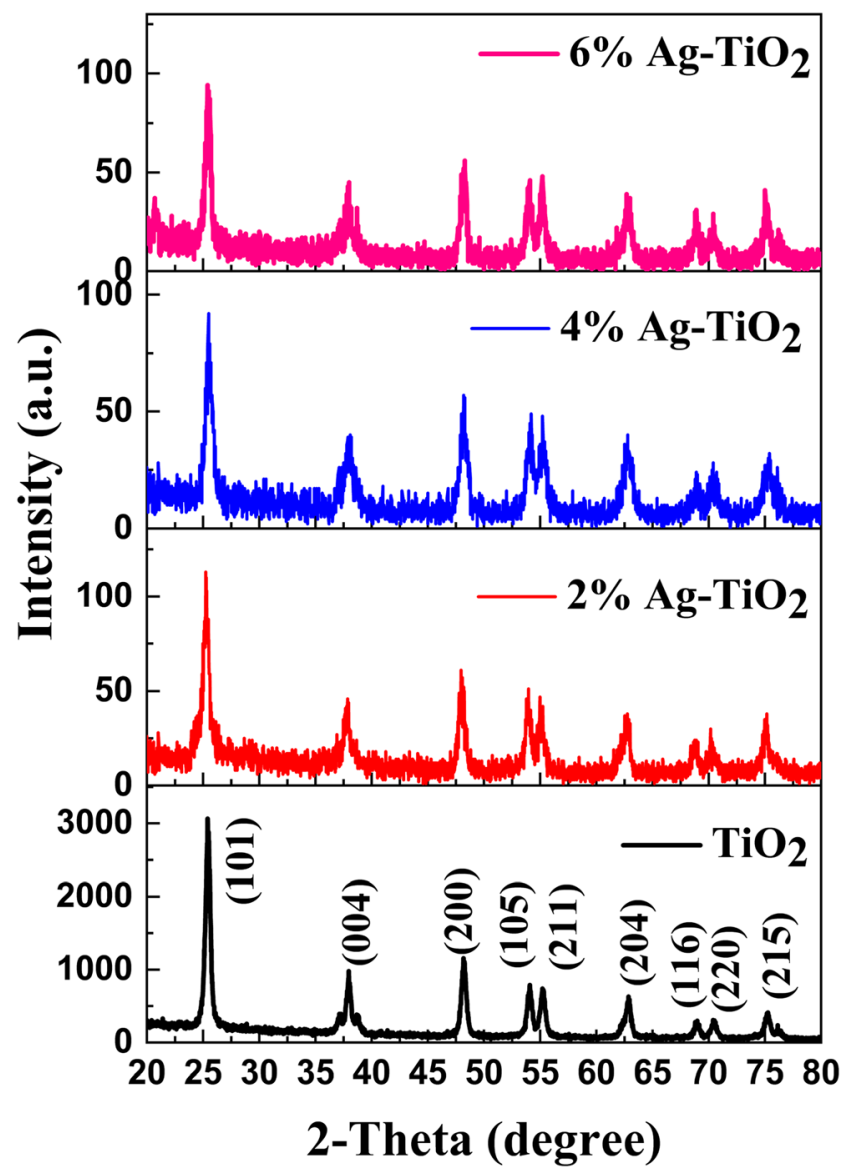

Fig. 3 XRD patterns of $\mathrm{TiO}_{2}$ and $\mathrm{Ag}-\mathrm{TiO}_{2}$ nanoparticles

The crystallite size of pristine $\mathrm{TiO}_{2}$ and $2 \%, 4 \%$ and $6 \% \mathrm{Ag}$ doped $\mathrm{TiO}_{2}$ was calculated to be $17.1 \mathrm{~nm}, 15 \mathrm{~nm}, 10.8 \mathrm{~nm}$ and $15.9 \mathrm{~nm}$, respectively, by the Debye Scherer equation. It is observed that as the Ag addition increases, the particle size reduces till optimum point then increases. There are no peaks related to $\mathrm{Ag}$ in $\mathrm{XRD}$ data, even for $6 \% \mathrm{Ag}-\mathrm{TiO}_{2}$, which suggests dopants are highly dispersed in the $\mathrm{TiO}_{2}$ samples [41]. For the $\mathrm{Ag}-\mathrm{TiO}_{2}$ nanoparticles, the (101) peak intensity was less compared to bare $\mathrm{TiO}_{2}$ nanoparticles. It should be noted that at low Ag contents, doping did not affect the

Table 1 Photophysical properties of $\mathrm{CaBa}$ dye

\begin{tabular}{llllll}
\hline Abs. $\lambda_{\max }{ }^{\mathrm{a}}(\mathrm{nm})$ & $\lambda_{\max } / \mathrm{TiO}_{2}{ }^{\mathrm{b}}(\mathrm{nm})$ & $\lambda_{\text {int }}^{\mathrm{c}}(\mathrm{nm})$ & $\mathrm{HOMO}^{\mathrm{d}}(\mathrm{vs} . \mathrm{NHE})(\mathrm{V})$ & $E_{0-0^{\mathrm{e}}(\mathrm{eV})}$ & $\mathrm{LUMO}{ }^{\mathrm{f}}(\mathrm{vs} . \mathrm{NHE})(\mathrm{V})$ \\
\hline 289.6 & 401.6 & 447 & 1.08 & 2.77 & -1.69 \\
326 & & & & & \\
394 & & & &
\end{tabular}

${ }^{a}$ Absorptions measured in THF

${ }^{\mathrm{b}}$ Maximum absorption on $\mathrm{TiO}_{2}$ film

${ }^{\mathrm{c}} \lambda_{\text {intersection }}$

${ }^{\mathrm{d}} \mathrm{HOMO}$ of dyes measured by cyclic voltammetry in $0.1 \mathrm{~N}$ tetraethylammonium tetrafluoroborate $\left(\mathrm{TEABF}_{4}\right)$ in acetonitrile

${ }^{\mathrm{e}} E_{0-0}=\frac{1240}{\lambda_{\text {int }}}$

${ }^{\mathrm{f}} E_{\mathrm{LUMO}}=E_{\mathrm{HOMO}}-E_{0-0}$ 
anatase crystalline phase; however, it affected the crystallinity of the product. $\mathrm{Ag}^{+}$or $\mathrm{Ag}^{2+}$ ions are introduced into the periodic $\mathrm{TiO}_{2}$ crystal lattice by causing strain into the system, and as a consequence, the lattice periodicity is altered and the crystal symmetry decreases [18].

\section{Morphology and structures of $\mathrm{TiO}_{2}$ and $4 \% \mathrm{Ag}-\mathrm{TiO}_{2}$}

High-resolution transmission electron microscopy (HRTEM) images of $\mathrm{TiO}_{2}$ and $4 \% \mathrm{Ag}-\mathrm{TiO}_{2}$ are displayed in Fig. $4 \mathrm{a}$ and $\mathrm{b}$ and $\mathrm{d}$ and e, respectively, and its selected area electron diffraction (SAED) patterns are displayed in Fig. 4c and $\mathrm{f}$, respectively. $\mathrm{TiO}_{2}$ and $4 \% \mathrm{Ag}-\mathrm{TiO}_{2}$ displayed almost spherical shaped particles with an average particle size of $17 \mathrm{~nm}$ and $11 \mathrm{~nm}$, respectively, which is in close agreement with the crystallite size obtained from the XRD. Interplanar spacing of $d=0.359 \mathrm{~nm}$ was displayed by $\mathrm{TiO}_{2}$ nanoparticles which is corresponding to the (101) plane of anatase $\mathrm{TiO}_{2}[42,43]$. On the other hand, interplanar spacing of $d=0.25 \mathrm{~nm}$ was displayed by $4 \% \mathrm{Ag}-\mathrm{TiO}_{2}$ nanoparticles which is corresponding to the (002) plane of $\mathrm{Ag}_{2} \mathrm{O}$ [44]. This confirms that $\mathrm{Ag}$ was effectively doped into the $\mathrm{TiO}_{2}[18,45]$. The anatase phase of both samples is further confirmed by SAED pattern [46]. In addition, EDAX spectrum (Fig. 5e) and mapping of elements (Fig. 5a-d) of $4 \%$ Ag-doped $\mathrm{TiO}_{2}$ indicate that $\mathrm{Ag}$ was successfully doped to the $\mathrm{TiO}_{2}$.

\section{Electrochemical performance of $\mathrm{TiO}_{2}$ and $4 \% \mathrm{Ag}-\mathrm{TiO}_{2}$}

Figure 6a displays the $\mathrm{CV}$ of $\mathrm{TiO}_{2}$ and $4 \% \mathrm{Ag}-\mathrm{TiO}_{2}$ recorded in an aqueous $0.5 \mathrm{M} \mathrm{KOH}$ solution, with a Pt counter electrode $(\mathrm{CE})$ and an $\mathrm{Ag} / \mathrm{AgCl}$ as the reference electrode. There is no measurable reduction or oxidation peak obtained for bare $\mathrm{TiO}_{2}$ within the potential scan range between -0.5 and $0.5 \mathrm{~V}$. But in the case 4\% Ag-doped electrode, the anodic (1 and 2) and cathodic (3 and 4) peaks were observed for $\mathrm{TiO}_{2}$ nanoparticle electrode which is attributed to the oxidation of $\mathrm{Ag}$ (1 $\left[\mathrm{Ag} / \mathrm{Ag}_{2} \mathrm{O}\right]$ and $\left.2\left[\mathrm{Ag}_{2} \mathrm{O} / \mathrm{AgO}\right]\right)$ and the reduction of silver oxide (3 $\left[\mathrm{AgO} / \mathrm{Ag}_{2} \mathrm{O}\right]$ and $\left.4\left[\mathrm{Ag}_{2} \mathrm{O} / \mathrm{Ag}\right]\right)$ [47-50].

To analyse the charge transfer kinetic property of $\mathrm{TiO}_{2}$ and $4 \% \mathrm{Ag}-\mathrm{TiO}_{2}$ nanoparticles, the EIS investigation was carried out under dark condition using the dummy cells. Dummy cells were fabricated with two identical electrodes and separated by electrolyte film. Figure $6 \mathrm{~b}$ shows the Nyquist plots of $\mathrm{TiO}_{2}$ and $4 \% \mathrm{Ag}-\mathrm{TiO}_{2}$ nanoparticles. It can be seen from Fig. $6 \mathrm{~b}$ that the grain boundary resistance of $4 \% \mathrm{Ag}-\mathrm{TiO}_{2}$ is lower than that of $\mathrm{TiO}_{2}$ which confirms the improvement in conducting behaviour of $4 \% \mathrm{Ag}-\mathrm{TiO}_{2}$. The doping of the $\mathrm{Ag}$ metal ion into the $\mathrm{TiO}_{2}$ matrix enhances the mobility of the prepared material and raises the charge carrier, confirming the fastest interfacial electron transfer and the lowest recombination rate within composite samples $[51,52]$.

Tafel plots of $4 \%$ Ag-doped and bare $\mathrm{TiO}_{2}$ are shown in Fig. 6c. The disparity in curve behaviour can be attributed to

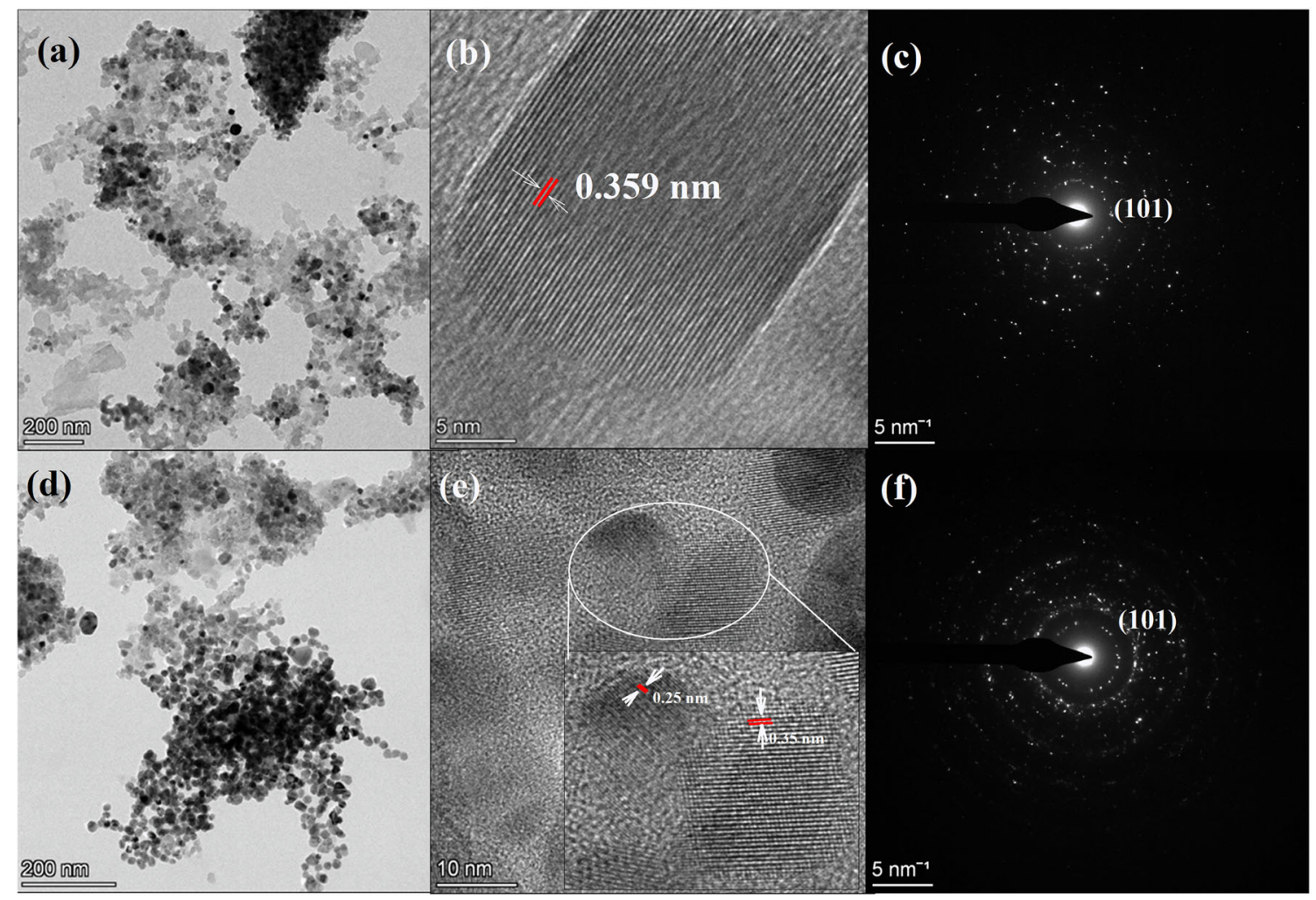

Fig. 4 HRTEM images of $\mathrm{TiO}_{2}(\mathbf{a}, \mathbf{b})$ and $4 \% \mathrm{Ag}-\mathrm{TiO}_{2}(\mathbf{d}, \mathbf{e})$ and $\mathrm{SAED}$ patterns of $\mathrm{TiO}_{2}(\mathbf{c})$ and $4 \% \mathrm{Ag}-\mathrm{TiO}_{2}(\mathbf{f})$ 

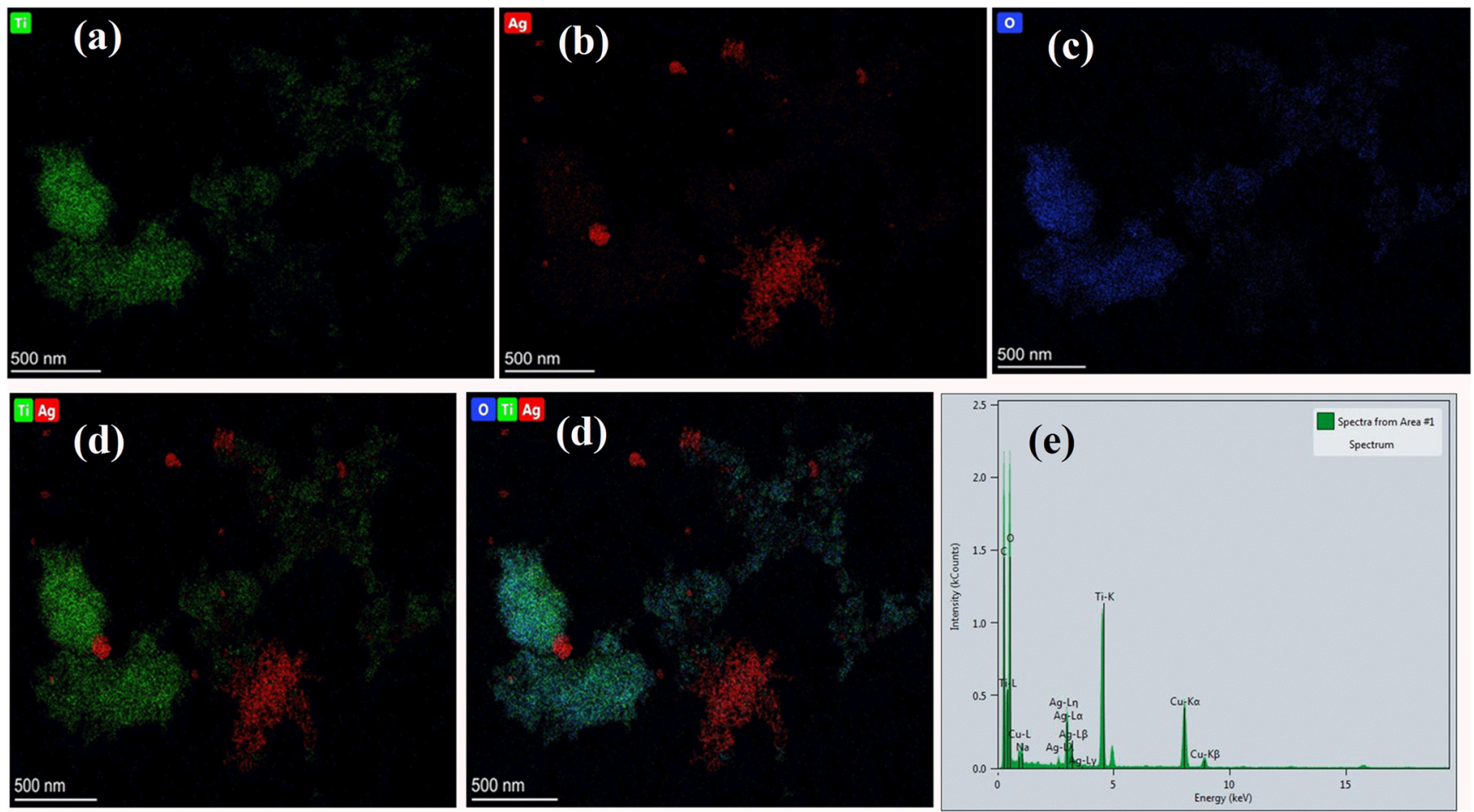

Fig. 5 Mapping of elements (a-d) and EDAX spectra (e) of $4 \% \mathrm{Ag}-\mathrm{TiO}_{2}$

(a)

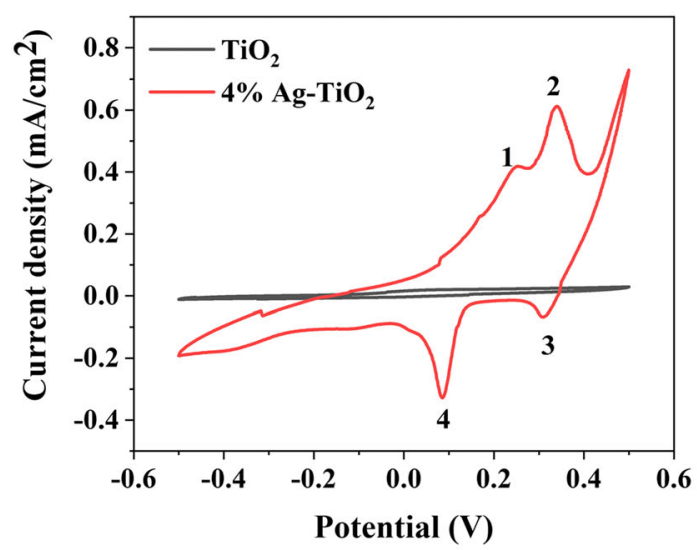

(b)

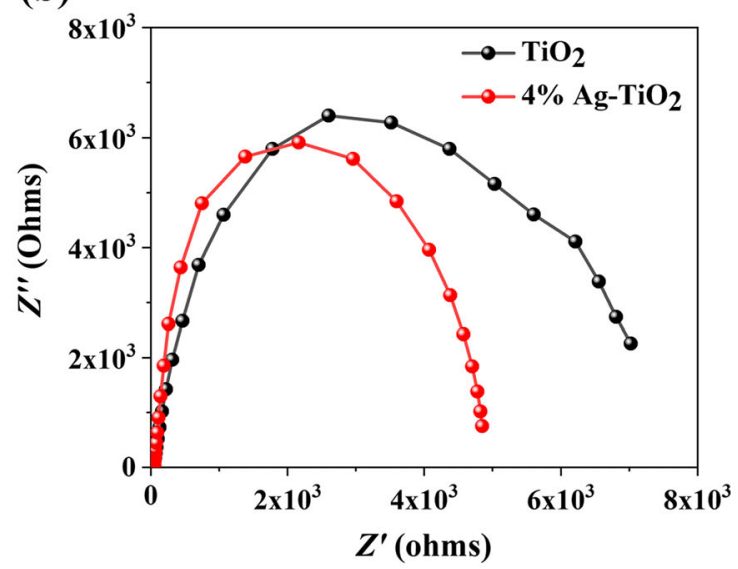

(c)

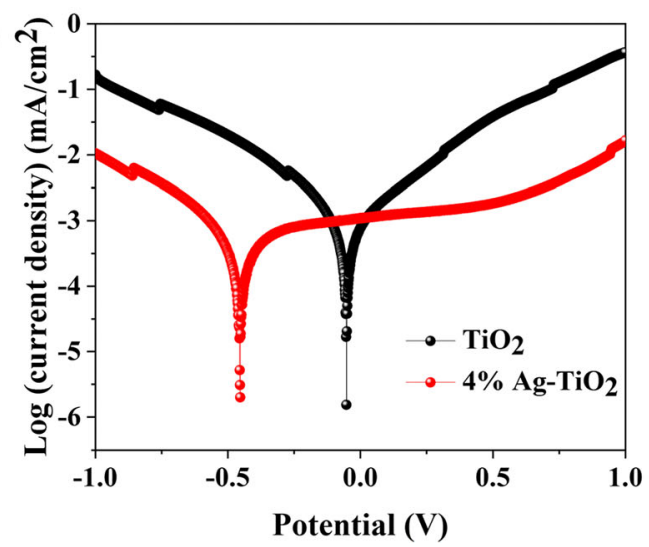

Fig. 6 a CV, b EIS and c Tafel plots of $\mathrm{TiO}_{2}$ and $4 \% \mathrm{Ag}-\mathrm{TiO}_{2}$ 

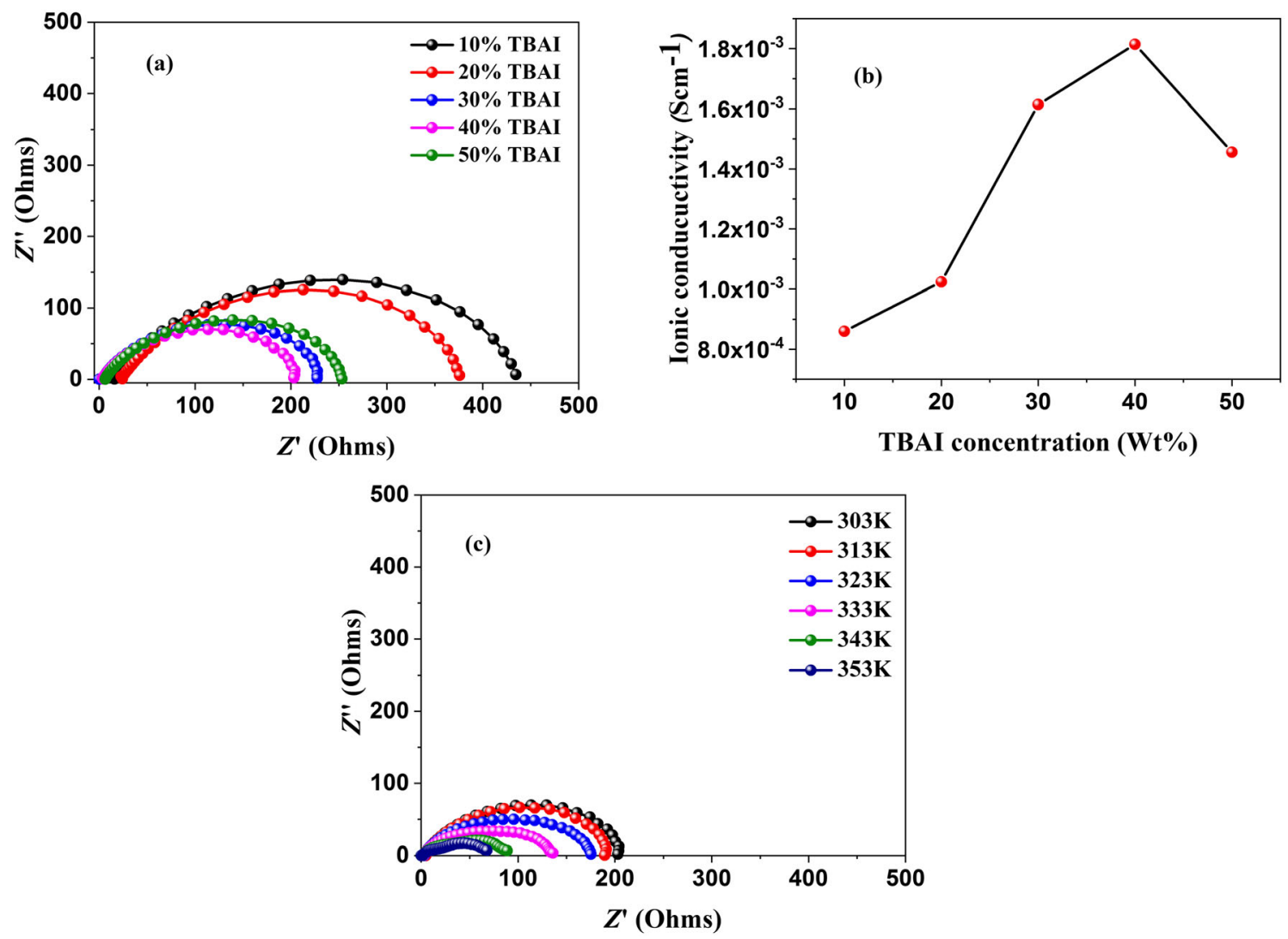

Fig. 7 a Complex impedance plots of BPE samples with different TBAI concentrations at room temperature. b Ionic conductivity of BPE samples. c Complex impedance plots of $40 \%$ TBAI sample at different temperatures

different processes of charge transfer at the interface of the photoanode. The charge will first fill the empty surface states below the conduction band edge with a negative bias applied to a semiconductor electrode and then accumulate in the space charge layer [53]. In contrast to the $\mathrm{TiO}_{2}$, the polarization curve of $4 \% \mathrm{Ag}-\mathrm{TiO}_{2}$ showed a negative shift, which implies the negative shift of $\mathrm{TiO}_{2}$ 's flat band potential $\left(E_{\mathrm{fb}}\right)$ after Ag doping. It is well known that $V_{\mathrm{OC}}$ is determined by the electrolyte's redox potential and the electrode's $E_{\mathrm{fb}}$; the $E_{\mathrm{fb}}$ change means the device's $V_{\mathrm{OC}}$ variation. A negative $E_{\mathrm{fb}}$ shift means a shift away from the redox potential and hence a rise in $V_{\mathrm{OC}}[54,55]$.

\section{Ionic conductivity studies of polymer electrolytes}

The bulk resistance of the prepared polymer electrolyte was obtained from complex impedance plots $\left(-Z^{\prime \prime}\right.$ vs. $\left.Z^{\prime}\right)$. Polymer electrolytes with 5 different TBAI ratios are illustrated in Fig. 7a. It was observed that the conductivity of blend polymer electrolytes (BPE) increases with the amount of TBAI till optimum point and then decreases. Among 5 different BPEs, $40 \%$ TBAI showed the maximum conductivity as shown in Fig. $7 \mathrm{~b}$. Mobility of free ions and charge density influence the conductivity of polymer electrolytes. By adding more salts, the number of free ion density charges can be promoted. However, if there is excess of free ions present in polymer electrolytes, they may have a tendency to form an aggregation of ions and pairings of ions. This phenomenon hindered the mobility of mobile charge carriers within the polymer matrix and therefore decreased ion conductivity [56]. The ionic conductivity studies of $40 \%$ TBAI BPE in the temperature range 303 to $353 \mathrm{~K}$ are shown in Fig. 7c. It was observed that, as the temperature increases, the conductivity also increases. As the temperature increases, the free ions acquire more kinetic energy and move more quickly; this phenomenon causes an increase in conductivity.

\section{Dielectric behaviour of polymer electrolyte}

Dielectric behaviour of polymer electrolytes can be explained using electrical and permittivity studies. Dielectric constant or real part $\left(\varepsilon^{\prime}\right)$ and dielectric loss or imaginary part $\left(\mathcal{E}^{\prime \prime}\right)$ are two complex dielectric parameters of permittivity dielectric studies. The variation of dielectric constant for all BPE samples with frequency is shown in Fig. S7(a). It was seen that at lower frequency, the dielectric constant for each sample is very large, and at the higher frequency, it decreases. At lower frequency, the mobile ions move around in the polymer matrixes under electric field and form a hetero-charge layer at electrode-electrolyte interface due to the accumulation of mobile ions at the interface which the layer will shield the external electrical field and later also led to the high value of the 
dielectric constant [24]. At the same time, mobile ions are hardly able to be aligned to the direction of the applied field at higher frequencies and this gives rise to a very fast periodic reversal of the electric field that there is no time for the charge to build up at the interface. Hence, the polarization due to the charge accumulation decreases, leading to a decrease in a dielectric constant $[57,58]$. The dielectric constant at different temperatures for the 40\% TBAI sample is shown in Fig. S7(b). From the graph, it can be understood that as the temperature increases, there is rise in the dielectric constant. At higher temperature, free ions move faster due to gaining of more kinetic energy. Hence, the ability of free ions to rotate and align with the externally applied fields leads to an increase in the dielectric constant. The frequency dependence of dielectric loss for all BPE samples is shown in Fig. S7(c). It was seen that the dielectric loss for each sample approaches zero and is very large at higher and lower frequency, respectively. Nevertheless, there is a complex molecular relaxation process as variations of points are present in the graph. The dielectric loss behaviour of a $40 \%$ TBAI sample at different temperatures is summarized in Fig. S7(d). The dielectric loss is following the trend of temperature. This can be explained by the facts that an increase in the rate of ion migration at high temperatures leads to an increase in the dielectric loss [23].

Electrical modulus studies were conducted to understand more about the relaxation behaviour of a polymer electrolyte. Figure S8(a) displays the real part modulus $\left(M^{\prime}\right)$ against frequency. At the higher-frequency region, dispersion of real part modulus takes place, and when it reaches lower frequency, it approaches zero. This actually indicates that at the electrodeelectrolyte interface, the occurrence of masking the electrode polarization effect can be observed. At the high-frequency region, resonance peaks are seen which indicate the samples are good ionic with a long range of conductivity relaxation [59]. Figure S8(b) displays the temperature dependence real modulus behaviour of $40 \%$ TBAI. It shows at low frequency, $M^{\prime}$ is very close to zero and, at the higher frequency, it disperses. The graph of imaginary part modulus $\left(M^{\prime \prime}\right)$ against frequency is presented in Fig. S8(c). The graph displays $M^{\prime \prime}$ dispersion at high frequency, and at the lower frequency, it approaches zero. The resonance peaks are not observed in the graph, but it may appear at higher frequency. The temperature
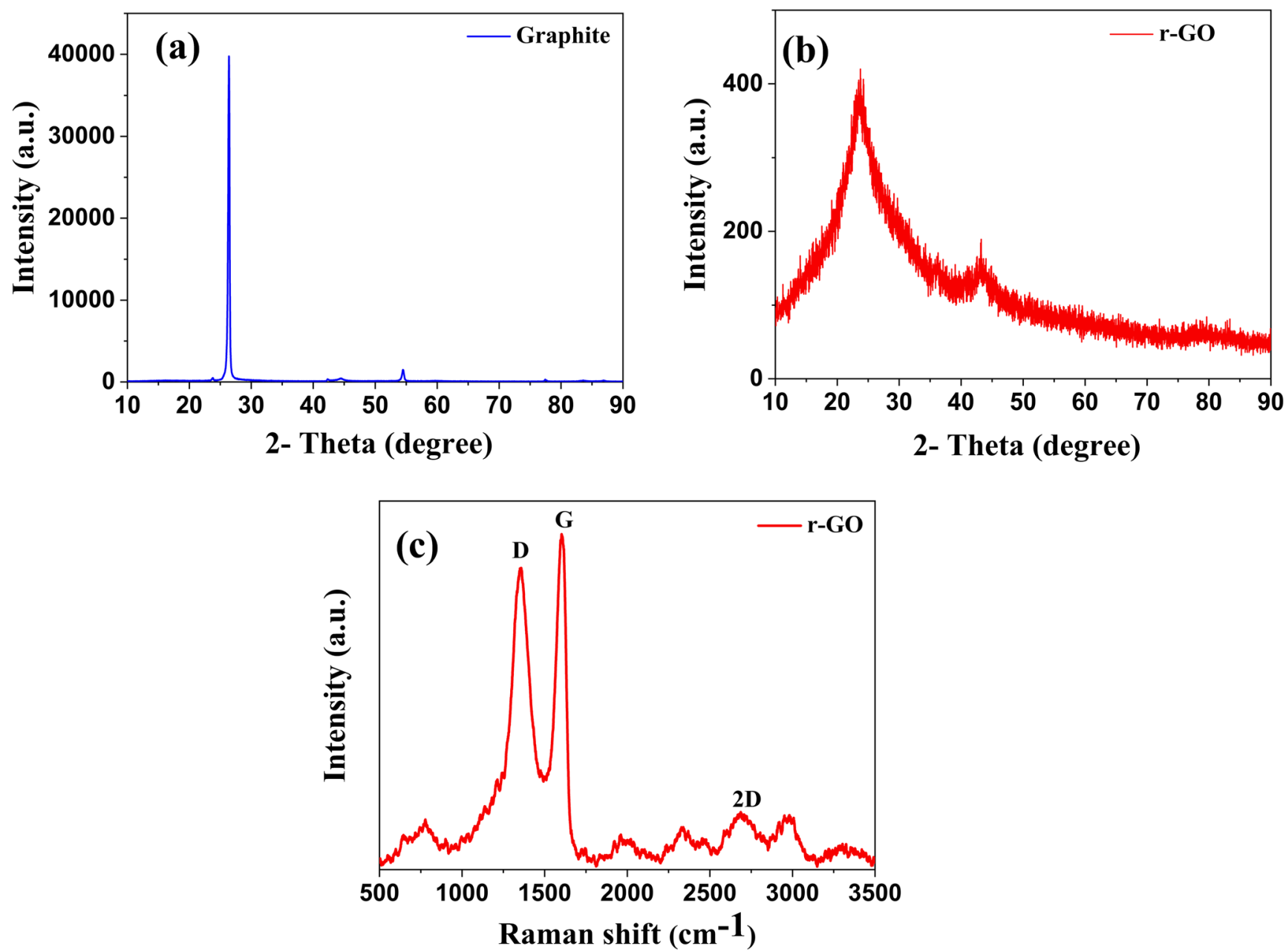

Fig. 8 a XRD spectra of graphite. b XRD spectra of r-GO. $\mathbf{c}$ Raman spectra of r-GO 
dependence imaginary part modulus of the $40 \%$ TBAI sample is exhibited in Fig. S8(d). It shows that the peaks were shifted towards high-frequency state which indicates the values of $M^{\prime \prime}$ are inversely proportional to temperature. Thus, it can be concluded that at the higher temperature, the relaxation time of the samples is shorter and it is thermally activated with the hopping of free ions [60].

\section{XRD and Raman spectra of r-GO}

Figure $8 \mathrm{a}$ and $\mathrm{b}$ shows the XRD pattern of graphite and $\mathrm{r}-\mathrm{GO}$, respectively. The XRD spectra of graphite showed an intense sharp peak at $26.4^{\circ}$ (interlayer spacing $=0.34 \mathrm{~nm}$ ) corresponding to the distinctive feature of graphite with the $h \mathrm{kl}$ parameter (002) [31]. In the XRD pattern of r-GO, the existence of a broad peak at $24.3^{\circ}$ suggests that the graphite was fully converted to $\mathrm{r}-\mathrm{GO}$. The broadening of the XRD graphene peak (002) was due to misalignments and faults in carbon sheet stacks with a larger carbon interlayer spacing [61].

Raman spectroscopy was carried out to characterize r-GO which is shown in Fig. 8c. It revealed D band and $G$ band at $1358.5 \mathrm{~cm}^{-1}$ and $1602.86 \mathrm{~cm}^{-1}$, respectively. The $\mathrm{D}$ band was observed due to the defects of $\mathrm{C}=\mathrm{C}$ in the $\mathrm{r}-\mathrm{GO}$, and the $\mathrm{G}$ band was observed due to the in-plane vibration of $\mathrm{C}-\mathrm{C}$. The intensity ratio of $\mathrm{D}$ and $\mathrm{G}$ bands demonstrates the quality of the $\mathrm{r}-\mathrm{GO}$. The $I_{\mathrm{D}} / I_{\mathrm{G}}$ value of $\mathrm{r}-\mathrm{GO}$ is 0.8475 . However, the prominent $\mathrm{D}$ peak in $\mathrm{r}-\mathrm{GO}$ suggests that certain structural defects such as vacancies and topological defects still exists after the reaction [62]. The spectra also showed a $2 \mathrm{D}$ peak at $2686.57 \mathrm{~cm}^{-1}$ which indicates the number of layers in graphene. The $2 \mathrm{D}$ band was found to be broadened, due to the fact that the prepared graphene comprises few layers with certain defects [63]. The results obtained for $\mathrm{r}-\mathrm{GO}$ by various research groups using different methods matched the results obtained in the present work [64-66].

\section{Morphological study of r-GO}

Figure 9a and $\mathrm{b}$ shows the HRTEM image of r-GO and its corresponding high-magnification image, respectively, and indicates the less wrinkled morphology with crystalline nature. The SAED pattern (Fig. 9c) showed strong diffraction spots with six-folded rotational symmetry with the outer spots corresponding to the $(110)$ planes $(d$-spacing $=0.119 \mathrm{~nm})$ and the innermost diffraction spots corresponding to the (100) planes $(d$-spacing $=0.201 \mathrm{~nm})$, which clearly indicates the graphitic crystalline structure [67].

\section{Electrochemical performance of $\mathrm{r}-\mathrm{GO}$ and $\mathrm{Pt}$}

To examine the catalytic activity and reaction kinetics of the Pt and r-GO CEs, CV was carried out using a three-electrode system in liquid electrolyte. Two redox peaks were noticed at higher and lower potentials in the $\mathrm{CV}$ graphs of $\mathrm{Pt}$ and $\mathrm{r}-\mathrm{GO}$ CEs (Fig. 10a) which are attributed to the reaction of $2 I_{3}^{-} \rightarrow 3$ $I_{2}+2 e^{-}$and $3 I^{-} \rightarrow I_{3}^{-}+2 e^{-}$, respectively [68, 69]. Two parameters, the peak-to-peak separation $\left(E_{\mathrm{pp}}\right)$ and the peak current, represent the catalytic activity of CEs [70]. A smaller $E_{\mathrm{pp}}$ implies greater reversibility of the redox reaction, and a faster reduction rate is demonstrated by a higher cathodic peak current density $[71,72]$. From Fig. $10 \mathrm{a}$, we can notice that the $E_{\mathrm{pp}}$ values for the Pt CE were lower compared to those for the rGO CE and the cathodic peak current density for the Pt CE is higher compared to that for r-GO. The lower $E_{\mathrm{pp}}$ and higher peak current density of Pt CE indicate good electroreductive behaviour to $\mathrm{I}^{-} / \mathrm{I}_{3}{ }^{-}$redox. These findings are in agreement with EIS experiment and DSSC with high efficiency.

EIS experiment was carried out using symmetric cells to further verify the electrocatalytic abilities of r-GO and Pt CEs. Figure 10b shows the EIS spectra of r-GO and Pt CEs with the equivalent circuit model in the inset. According to the
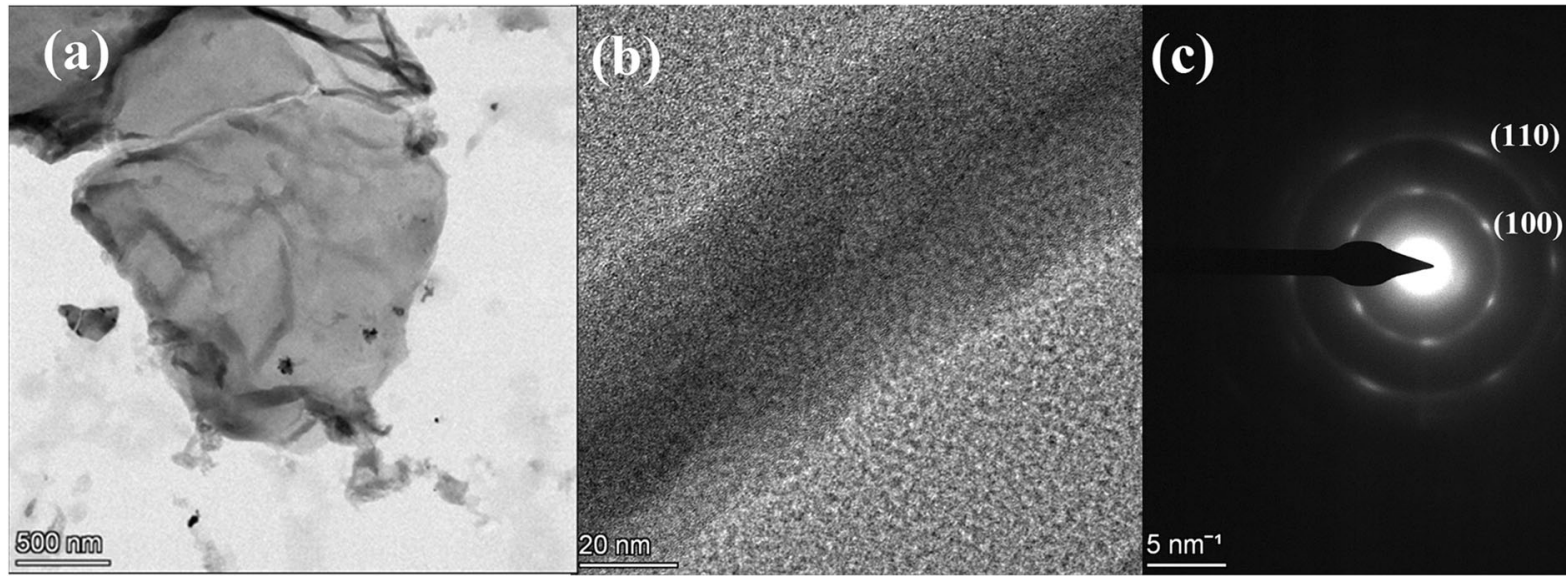

Fig. 9 HRTEM images $(\mathbf{a}, \mathbf{b})$ and SAED pattern $(\mathbf{c})$ of r-GO 
(a)

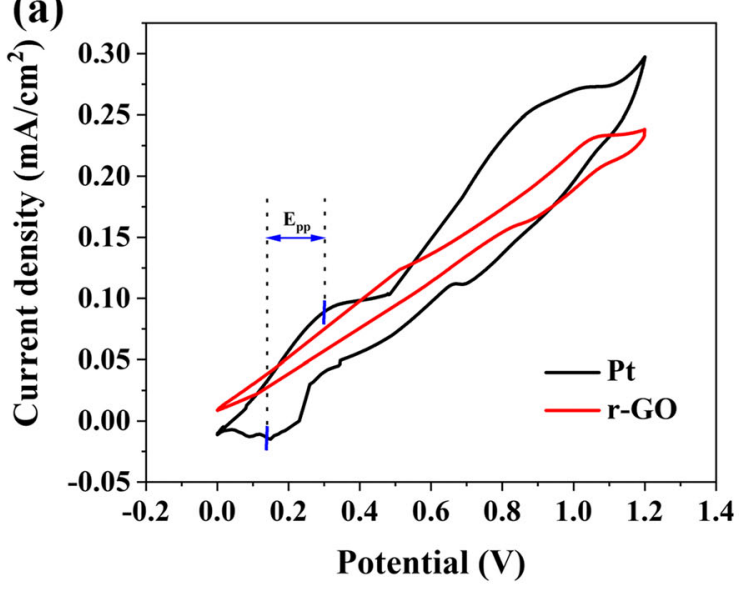

(b)

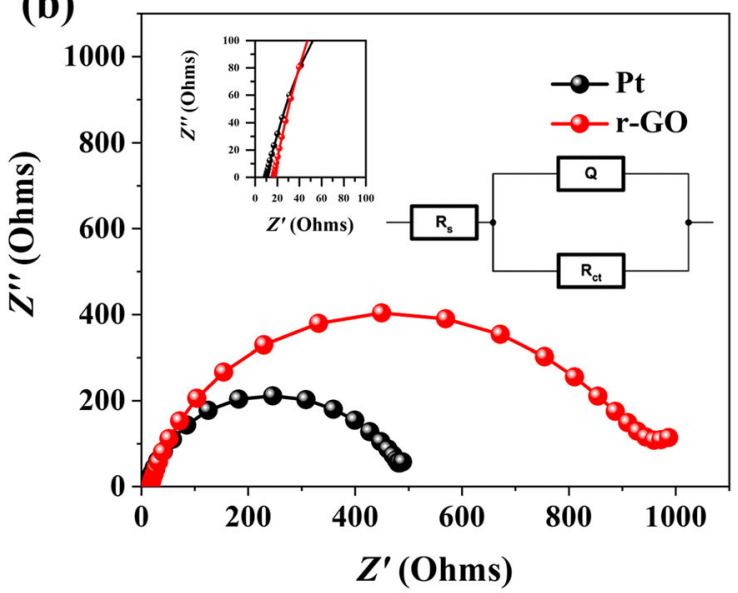

(c)

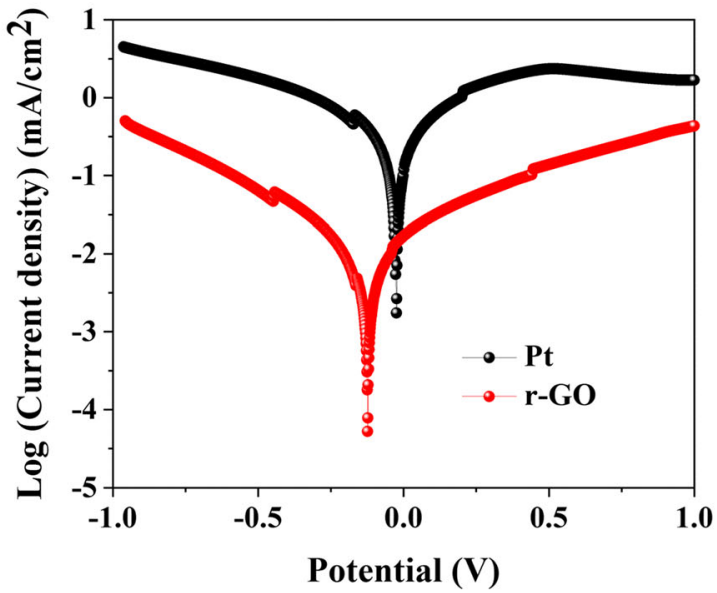

Fig. 10 a CV, b EIS and $\mathbf{c}$ Tafel plots of Pt and r-GO CEs

equivalent circuit, the semicircle represents the charge transfer resistance $\left(R_{\mathrm{ct}}\right)$ at the interface of the CE/electrolyte and the series resistance $\left(R_{\mathrm{S}}\right)$ represented by the intercept in high frequency on the real axis, where catalytic activity of CEs was represented by $R_{\mathrm{ct}}$ [73]. From the Nyquist plot and equivalent circuit of Pt and r-GO CEs, it is noticeable that the Pt's $R_{\mathrm{s}}$ $(9.83 \Omega)$ is lower than r-GO's $(16.73 \Omega)$, which can be due to Pt's superior electrical conductivity. Furthermore, the $R_{\mathrm{ct}}$ is in the order of r-GO $(959 \Omega)>\mathrm{Pt}(481.5 \Omega)$, showing the effective transfer of charge between surfaces of $\mathrm{I}_{3}{ }^{-}$and $\mathrm{Pt} \mathrm{CE}$.
To examine the interfacial charge transfer behaviour of CE/ electrolyte, the Tafel polarization curves were analysed using the symmetric cells. Tafel polarization curves of $\mathrm{Pt}$ and $\mathrm{r}-\mathrm{GO}$ CEs are represented in Fig. 10c. Exchange current density $\left(J_{0}\right)$ is inversely proportional to $R_{\mathrm{ct}}$; therefore, a good CE should have lower $R_{\mathrm{ct}}$ which produces higher $J_{0} . J_{0}$ can be estimated from the tangent line intersection of the polarization curve and the linear segment extension to the zero bias $[74,75] . J_{\lim }$ relies on the $\mathrm{I}^{-} / \mathrm{I}_{3}{ }^{-}$redox pair diffusion coefficient. Pt exhibits a higher $J_{\text {lim }}$ relative to $\mathrm{r}-\mathrm{GO}$ from the Tafel graph. A lower

Table 2 Photovoltaic parameters obtained from $J-V$ curves

\begin{tabular}{|c|c|c|c|c|c|c|}
\hline Code & Materials & $V_{\mathrm{OC}}(\mathrm{V})$ & $J_{\mathrm{SC}}\left(\mathrm{mA} \mathrm{cm}^{-2}\right)$ & $\mathrm{FF} \%$ & PCE \% & $R_{\mathrm{ct}}(\Omega)$ \\
\hline Device 1 & $\mathrm{TiO}_{2} / \mathrm{CaBa}$ dye $/ 40 \% \mathrm{TBAI} / \mathrm{r}-\mathrm{GO}$ & 0.37 & 3.9 & 41 & 0.59 & 3889 \\
\hline Device 2 & $2 \% \mathrm{Ag}-\mathrm{TiO}_{2} / \mathrm{CaBa}$ dye $/ 40 \% \mathrm{TBAI} / \mathrm{r}-\mathrm{GO}$ & 0.49 & 4.09 & 38 & 0.77 & 4938 \\
\hline Device 3 & $4 \% \mathrm{Ag}-\mathrm{TiO}_{2} / \mathrm{CaBa}$ dye $/ 40 \% \mathrm{TBAI} / \mathrm{r}-\mathrm{GO}$ & 0.5 & 4.54 & 47 & 1.06 & 7187 \\
\hline Device 4 & $6 \% \mathrm{Ag}-\mathrm{TiO}_{2} / \mathrm{CaBa}$ dye $/ 40 \% \mathrm{TBAI} / \mathrm{r}-\mathrm{GO}$ & 0.49 & 4.2 & 38 & 0.8 & 5904 \\
\hline Device 5 & $4 \% \mathrm{Ag}-\mathrm{TiO}_{2} / \mathrm{CaBa}$ dye $/ 40 \% \mathrm{TBAI} / \mathrm{Pt}$ & 0.59 & 5.43 & 52 & 1.7 & 7656 \\
\hline Device 6 & $4 \% \mathrm{Ag}^{-\mathrm{TiO}_{2}} / \mathrm{CaBa}$ dye $/ 40 \% \mathrm{TBAI} / \mathrm{Pt}$ & 0.64 & 6.61 & 55 & 2.37 & 9678 \\
\hline
\end{tabular}


Table 3 Photovoltaic parameters device with different materials obtained from $J-V$ curves

\begin{tabular}{|c|c|c|c|c|c|c|}
\hline Materials (anode/dye/electrolyte/CE) & $V_{\mathrm{OC}}$ & $J_{\mathrm{SC}}\left(\mathrm{mA} \mathrm{cm}^{-2}\right)$ & $\mathrm{FF} \%$ & PCE \% & Synthesis method (anode/cathode) & Ref. \\
\hline $\mathrm{TiO}_{2} / \mathrm{CaBa} /$ polymer/r-GO & 0.37 & 3.9 & 41 & 0.59 & $\begin{array}{l}\text { Modified sol-gel method/one-pot } \\
\text { chemical exfoliation method }\end{array}$ & This work \\
\hline $2 \% \mathrm{Ag}-\mathrm{TiO}_{2} / \mathrm{CaBa} /$ polymer/r-GO & 0.49 & 4.09 & 38 & 0.77 & $\begin{array}{l}\text { Modified sol-gel method/one-pot } \\
\text { chemical exfoliation method }\end{array}$ & This work \\
\hline $4 \% \mathrm{Ag}^{-\mathrm{TiO}_{2}} / \mathrm{CaBa} /$ polymer$/ \mathrm{r}-\mathrm{GO}$ & 0.5 & 4.54 & 47 & 1.06 & $\begin{array}{l}\text { Modified sol-gel method/one-pot } \\
\text { chemical exfoliation method }\end{array}$ & This work \\
\hline $6 \% \mathrm{Ag}^{-\mathrm{TiO}_{2}} / \mathrm{CaBa} /$ polymer$/ \mathrm{r}-\mathrm{GO}$ & 0.49 & 4.2 & 38 & 0.8 & $\begin{array}{l}\text { Modified sol-gel method/one-pot } \\
\text { chemical exfoliation method }\end{array}$ & This work \\
\hline $4 \% \mathrm{Ag}^{-\mathrm{TiO}_{2}} / \mathrm{CaBa} /$ polymer $/ \mathrm{Pt}$ & 0.59 & 5.43 & 52 & 1.7 & Modified sol-gel method & This work \\
\hline $4 \% \mathrm{Ag}^{-\mathrm{TiO}_{2}} / \mathrm{CaBa} /$ polymer $/ \mathrm{Pt}$ & 0.64 & 6.61 & 55 & 2.37 & Modified sol-gel method & This work \\
\hline $\mathrm{TiO}_{2} / \mathrm{N} 719 /$ liquid/Pt & 0.69 & 13.25 & 55 & 5.05 & Hydrothermal & {$[18]$} \\
\hline $\mathrm{Ag}_{0.10}-\mathrm{TiO}_{2} / \mathrm{N} 719 /$ liquid/Pt & 0.67 & 17.2 & 56 & 6.44 & Hydrothermal & {$[18]$} \\
\hline $\mathrm{TiO}_{2} / \mathrm{N} 719 /$ liquid/Pt & 0.66 & 7.34 & 56 & 2.75 & Chemical reduction & {$[21]$} \\
\hline $\mathrm{Ag}_{0.1 \mathrm{M}^{-}}-\mathrm{TiO}_{2} / \mathrm{N} 719 /$ liquid/Pt & 0.75 & 12.29 & 61 & 5.66 & Chemical reduction & {$[21]$} \\
\hline $\mathrm{TiO}_{2}(\mathrm{P} 25) / \mathrm{N} 719 /$ liquid/Pt & 0.64 & 16.62 & 51 & 5.55 & Commercial & [19] \\
\hline $\mathrm{Ag} @ \mathrm{TiO}_{2}$ core-shell/N719/liquid/Pt & 0.65 & 11.3 & 49 & 3.64 & Chemical reduction & {$[19]$} \\
\hline $\mathrm{P} 25: \mathrm{Ag} @ \mathrm{TiO}_{2}=70: 30$ wt\%/N719/liquid/Pt & 0.64 & 18.22 & 52 & 6.06 & Physical mixture & {$[19]$} \\
\hline $\mathrm{TiO}_{2}(\mathrm{P} 25) / \mathrm{N} 719 /$ liquid/Pt & 0.76 & 7.48 & 58 & 3.35 & Commercial & {$[78]$} \\
\hline UV-1.3\% Ag-TiO $/$ /N719/liquid/Pt & 0.8 & 8.36 & 56 & 3.85 & Photochemical reduction & {$[78]$} \\
\hline Glucose-1.3\% Ag-TiO $/ 2 / \mathrm{N} 719 /$ liquid/Pt & 0.8 & 10.72 & 52 & 4.54 & Chemical reduction & {$[78]$} \\
\hline Syzygium-1.3\% Ag- $\mathrm{TiO}_{2} / \mathrm{N} 719 /$ liquid/Pt & 0.79 & 11.8 & 54 & 5.12 & Chemical reduction & {$[78]$} \\
\hline $\mathrm{TiO}_{2} / \mathrm{N} 719 /$ liquid/r-GO & 0.75 & 12.9 & 49 & 4.86 & Thermal reduction & {$[62]$} \\
\hline $\mathrm{TiO}_{2} / \mathrm{N} 719 /$ liquid/Pt & 0.74 & 13.2 & 54 & 5.24 & Thermal reduction & {$[62]$} \\
\hline $\mathrm{TiO}_{2} / \mathrm{N} 719 /$ liquid/r-GO & 0.69 & 15.57 & 51 & 5.57 & Hydrothermal reduction & {$[27]$} \\
\hline $\mathrm{TiO}_{2} / \mathrm{N} 719 /$ liquid/Pt & 0.71 & 16.21 & 66 & 7.58 & Hydrothermal reduction & {$[27]$} \\
\hline $\mathrm{TiO}_{2} / \mathrm{N} 719 /$ liquid/r-GO & 0.72 & 9.22 & 63 & 4.16 & Photothermal reduction & {$[79]$} \\
\hline $\mathrm{TiO}_{2} / \mathrm{N} 719 /$ liquid/Pt & 0.7 & 9.94 & 68 & 4.72 & Photothermal reduction & [79] \\
\hline $\mathrm{TiO}_{2} / \mathrm{N} 719 /$ liquid/r-GO & 0.55 & 10.68 & 58 & 3.44 & Hydrothermal reduction & [69] \\
\hline $\mathrm{TiO}_{2} / \mathrm{N} 719 /$ liquid/Pt & 0.61 & 13.14 & 72 & 5.78 & Hydrothermal reduction & {$[69]$} \\
\hline
\end{tabular}

$J_{\text {lim }}$ of r-GO value shows that r-GO's electrocatalytic activity is weak. The $J_{0}$ values also display a pattern close to the $J_{\text {lim }}$ values, where r-GO showed less $J_{0}$ than Pt. A higher $J_{0}$ suggests that Pt has high electrocatalytic activity to convert triiodide to iodide, whereas a higher $J_{\lim }$ implies strong electrolyte interaction and improved diffusion inside the CE [76, 77].

\section{Photovoltaic performance}

The photovoltaic performance of DSSCs under standard AM 1.5 illumination is summarized in Table 2. Figure 10a depicts the current density $(J)$ versus potential $(V)$ plots of different fabricated cells. It was found that $\mathrm{Ag}$-doped $\mathrm{TiO}_{2}$ nanoparticles showed higher solar conversion efficiency $(\eta)$ and photocurrent density $\left(J_{\mathrm{SC}}\right)$ than the bare $\mathrm{TiO}_{2}$ nanoparticles. Among different Ag-doped $\mathrm{TiO}_{2}, 4 \% \mathrm{Ag}-\mathrm{TiO}_{2}$ showed the best photovoltaic properties due to their small size, which implies that a large number of dye molecules could be adsorbed. Greater absorption of visible light may enhance the use of sunlight. Nevertheless, the $\mathrm{Ag}-\mathrm{TiO}_{2}$ nanoparticles display an open- circuit voltage $\left(V_{\mathrm{OC}}\right)$ higher than the $\mathrm{TiO}_{2}$ nanoparticles. Also compared to r-GO CE-based DSSC, Pt CE-based DSSC displayed higher efficiency. This lower efficiency was mainly due to the less purity of r-GO. As shown by FTRaman experiments, the $\mathrm{r}-\mathrm{GO}$ sample has some residual oxygen-containing functional groups after reduction. Over the course of the photochemical process, the presence of these functional groups will greatly influence the electron transfer kinetics of CEs. In particular, the redox potential and charge transfer resistance will be altered, which can greatly affect the $\mathrm{FF}, J_{\mathrm{SC}}$ and $\eta$. This is reinforced by the higher $R_{\mathrm{ct}}$ value of $\mathrm{r}$ GO relative to Pt, found in CE EIS measurements (Fig. 10b). The photovoltaic parameters obtained in our work and in the previous studies are summarized in Table 3.

\section{EIS analysis of DSSCs}

The EIS spectra of DSSCs are shown in Fig. 11b, and their equivalent circuit is shown in the inset of Fig. 11b. A typical DSSC EIS spectrum consists of three semicircles. Details on 
(a)

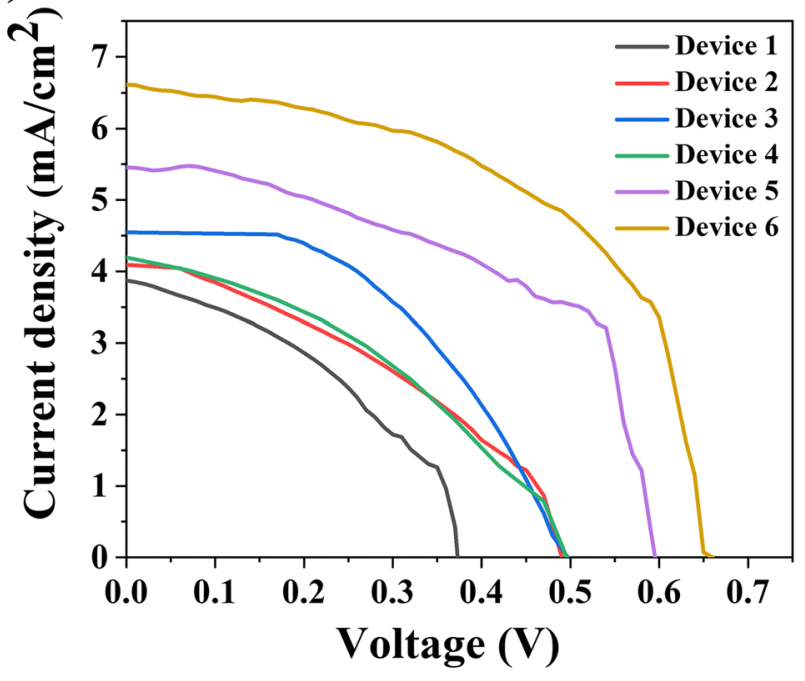

(b)

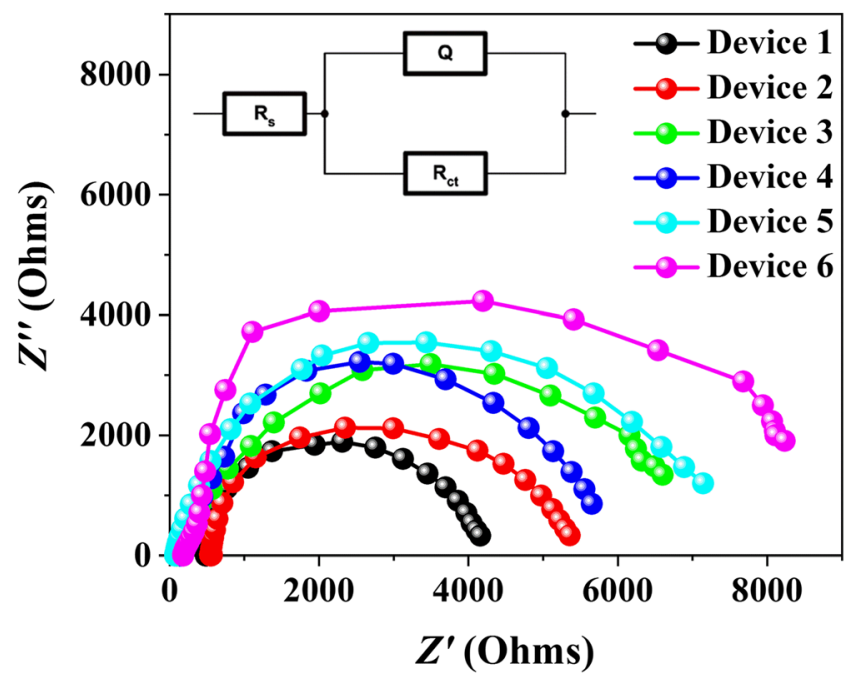

Fig. 11 a Current-potential characteristic of the DSSCs under AM 1.5 illumination. b EIS spectra of DSSCs

the charge transfer resistance at the $\mathrm{CE}$ can be obtained at high frequency, whereas at moderate frequency, electron transport in the photoanode and the back reaction at the interface of photoanode and electrolyte could be obtained. In addition,

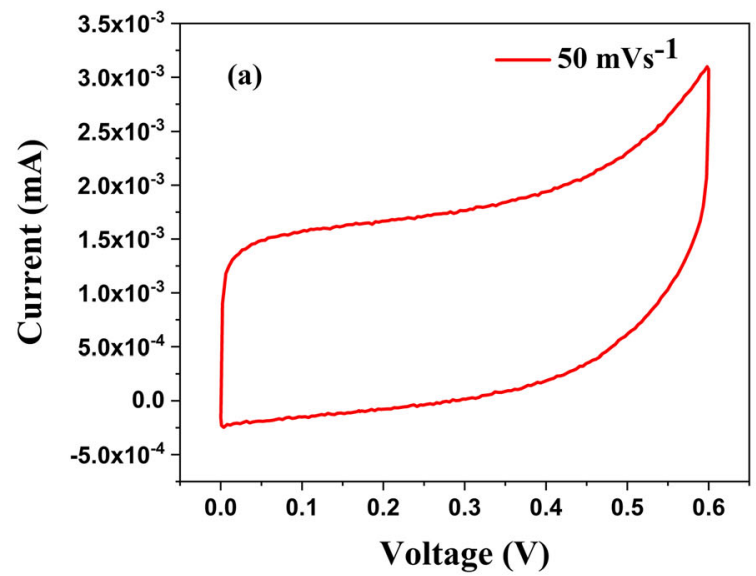

diffusion of redox mediator in electrolyte was evaluated using a low-frequency semicircle $[80,81]$. Just one semicircle was found in our case. This is because this semicircle occupies and obstructs our ability to view the other two smaller semicircles.

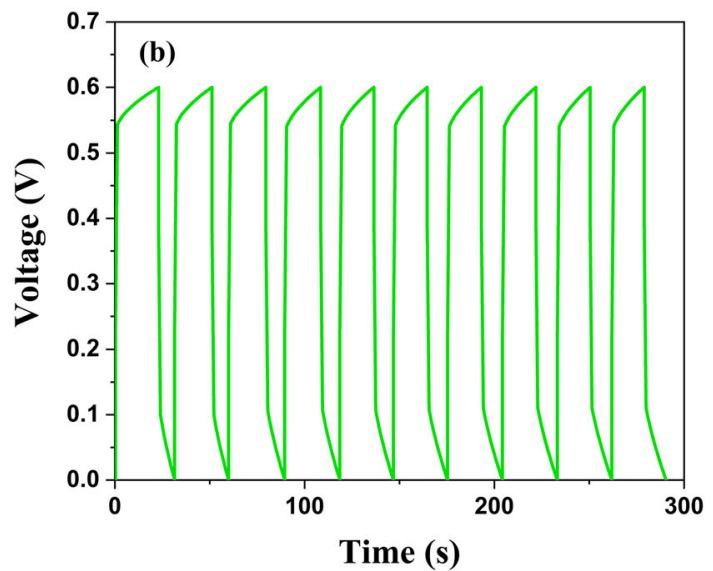

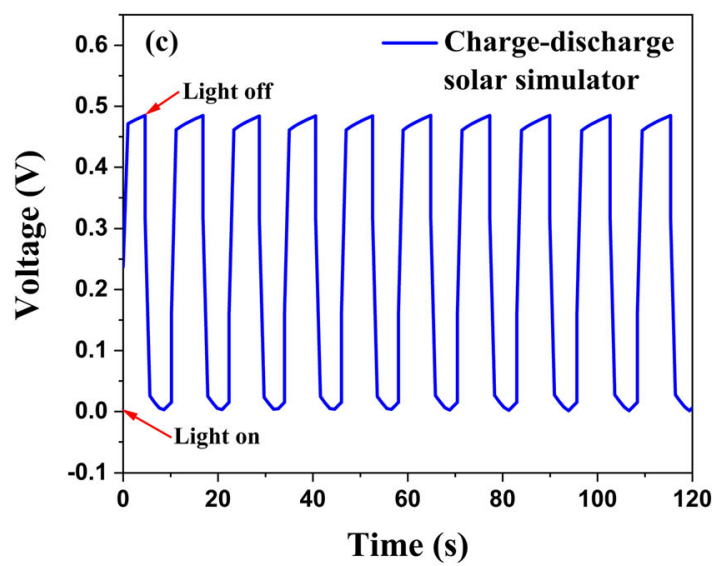

Fig. 12 Electrochemical characterization of SC and DSSC-SC device. a Cyclic voltammogram of SC. b Charge-discharge curve of SC with constant current density $0.4 \mathrm{~mA} \mathrm{~cm}{ }^{-2}$. c Charge-discharge profiles of an integrated device which was charged using AM 1.5 illumination and then discharged at a constant current density of $0.4 \mathrm{~mA} \mathrm{~cm}^{-2}$ 
Interface resistance of working electrode is directly proportional to the diameter of this semicircle. Low interface resistance leads to a higher recombination rate of charges and results in a lower current density [82, 83]. From Fig. 11b, we can clearly observe that interface resistance follows the order of device $1<$ device $2<$ device $3<$ device $4<$ device $5<$ device 6 which is in good agreement with current density results listed in Table $2 . R_{\mathrm{ct}}$ values obtained using equivalent circuit are displayed in Table 2. $R_{\mathrm{ct}}$ is at its highest value of $9678 \Omega$ for device 6 and at its lowest value of $3889 \Omega$ for device 1 which corresponds to the highest and lowest $J_{\mathrm{SC}}$, respectively.

\section{Performance of SC and DSSC-SC-integrated device}

Cyclic voltammetry and charge/discharge tests are used to characterize an integrated device. Figure 12 a depicts the CV curves of SC which were made from r-GO films as electrodes and $40 \%$ TBAI as electrolyte at a potential range of 0 to $0.6 \mathrm{~V}$ and under a sweep rate of $50 \mathrm{mV} \mathrm{s}^{-1}$. There are two categories in SC, i.e. a pseudo-capacitor and an electric double-layer capacitor. The CV curve displayed a rectangular shape without current peaks, indicating that the r-GO electrode possesses electrical double layer capacitance [84]. Accordingly, Fig. 12b depicts the charge/ discharge at a constant current density of $0.4 \mathrm{~mA} \mathrm{~cm}{ }^{-2}$. The discharge time of SC was observed to be about $8.43 \mathrm{~s}$, and the specific capacitance of the device was calculated to be 1.72 $\mathrm{Fg}^{-1}$. Figure 12c depicts the photocharge and discharge of the integrated device. Here, AM 1.5 illumination was used for photocharge and discharge was made with the constant current density of $0.4 \mathrm{~mA} \mathrm{~cm}{ }^{-2}$. During photocharging, the voltage increased to $0.485 \mathrm{~V}$, which was slightly lower than $V_{\mathrm{OC}}$ in the photoelectric conversion measurement due to electric power lost in the external circuit [85]. The discharge time and specific capacitance of the integrated device were calculated to be $5.23 \mathrm{~s}$ and $1.327 \mathrm{Fg}^{-1}$, respectively.

\section{Conclusion}

In summary, we synthesized a novel carbazole-based dye with a carbazole-donating unit and acid group as an acceptor unit and confirmed using IR, NMR and mass spectroscopy. $\mathrm{TiO}_{2}$ and Ag-doped $\mathrm{TiO}_{2}$ were synthesized using a modified sol-gel method and characterized by XRD and TEM analysis. Different concentrations of TBAI in PVA-PVP blend polymer electrolytes were prepared, and their conductivity was studied. Among different concentrations, 40\% TBAI electrolyte showed the highest conductivity of $1.76 \mathrm{mS} \mathrm{cm}{ }^{-1}$. $\mathrm{r}-\mathrm{GO}$ was synthesized by a one-pot synthesis method and confirmed using XRD and FT-Raman. DSSCs were fabricated using 40\% TBAI electrolyte (due to its high conductivity), bare $\mathrm{TiO}_{2}$ and $2 \%, 4 \%$ and $6 \%$ Ag-doped $\mathrm{TiO}_{2}$ as anode and r-GO as CE. Among them, device 3 showed the highest efficiency of $1.06 \%$. Due to its high efficiency among r-GO CE-based DSSCs, this device was used to develop a DSSC-SC-integrated device. The integrated device was tested via photocharging using AM 1.5 illumination and discharging at constant current density. From the results obtained, we conclude that synthesized dye can be used as sensitizer in DSSC and fabricated device successfully converts solar energy to electrical energy which simultaneously stores electrical energy in SC. Further for comparison, device 5 and device 6 were fabricated which have Pt as CE. Device 5 and device 6 displayed the highest efficiency of $1.7 \%$ and $2.37 \%$, respectively, compared to r-GO-based devices which are mainly due to high catalytic activity of Pt compared to that of r-GO. The rGO-based DSSC's lower performance was found to be due to a higher resistance to charge transfer and relatively lower electrocatalytic activity relative to the Pt-based CE. In order to decrease the resistance to charge transfer and increase cell performance, more optimization in the reaction condition is important. The rGO preparation defined in this paper is environmentally safe, lower cost and scalable. The r-GO obtained is found to be appropriate for DSSC counter electrode applications, and further process optimization is likely to enhance its efficiency to equal that of traditional DSSCs based on Pt.

Abbreviations $\quad C V$, Cyclic voltammetry; DSSC, Dye-sensitized solar cell; $S C$, Supercapacitor; $T T I P$, Titanium tetraisopropoxide; $X R D$, X-ray diffraction

Supplementary Information The online version contains supplementary material available at https://doi.org/10.1007/s10008-021-04920-2.

Funding Open access funding provided by Manipal Academy of Higher Education, Manipal.

Open Access This article is licensed under a Creative Commons Attribution 4.0 International License, which permits use, sharing, adaptation, distribution and reproduction in any medium or format, as long as you give appropriate credit to the original author(s) and the source, provide a link to the Creative Commons licence, and indicate if changes were made. The images or other third party material in this article are included in the article's Creative Commons licence, unless indicated otherwise in a credit line to the material. If material is not included in the article's Creative Commons licence and your intended use is not permitted by statutory regulation or exceeds the permitted use, you will need to obtain permission directly from the copyright holder. To view a copy of this licence, visit http://creativecommons.org/licenses/by/4.0/.

\section{References}

1. Hemavathi B, Jayadev V, Pradhan SC, Gokul G, Jagadish K, Chandrashekara GK, Ramamurthy PC, Pai RK, Narayanan Unni KN, Ahipa TN, Soman S, Geetha Balakrishna R (2018) Aggregation induced light harvesting of molecularly engineered D-A-П-A carbazole dyes for dye-sensitized solar cells. Sol Energy 174:1085-1096. https://doi.org/10.1016/j.solener.2018.09. 073 
2. Han L, Liu J, Liu Y, Cui Y (2019) Novel D-A- $\pi$-A type benzocarbazole sensitizers for dye sensitized solar cells. J Mol Struct 1180:651-658. https://doi.org/10.1016/j.molstruc.2018.12. 052

3. Kumar D, Wong KT (2017) Organic dianchor dyes for dyesensitized solar cells. Mater Today Energy 5:243-279. https://doi. org/10.1016/j.mtener.2017.05.007

4. Ji JM, Zhou H, Kim HK (2018) Rational design criteria for D- $\pi$-A structured organic and porphyrin sensitizers for highly efficient dye-sensitized solar cells. J Mater Chem A 6(30):14518-14545. https://doi.org/10.1039/c8ta02281j

5. Han L, Islam A, Chen H, Malapaka C, Chiranjeevi B, Zhang S, Yang X, Yanagida M (2012) High-efficiency dye-sensitized solar cell with a novel co-adsorbent. Energy Environ Sci 5(3):60576060. https://doi.org/10.1039/c2ee03418b

6. Kang SH, Jeong MJ, Eom YK, Choi IT, Kwon SM, Yoo Y, Kim J, Kwon J, Park JH, Kim HK (2017) Porphyrin sensitizers with donor structural engineering for superior performance dye-sensitized solar cells and tandem solar cells for water splitting applications. Adv Energy Mater 7(7):1-10. https://doi.org/10.1002/aenm.201602117

7. Humphry-Baker R, Rothlisberger U, Nazeeruddin MK et al (2014) Dye-sensitized solar cells with $13 \%$ efficiency achieved through the molecular engineering of porphyrin sensitizers. Nat Chem 6(3): 242-247. https://doi.org/10.1038/nchem. 1861

8. Mishra A, Fischer MKR, Büuerle P (2009) Metal-free organic dyes for dye-sensitized solar cells: from structure: property relationships to design rules. Angew Chem Int Ed 48(14):2474-2499. https://doi. org/10.1002/anie.200804709

9. Ji JM, Kim SH, Zhou H, Kim CH, Kim HK (2019) D- $\pi$-Astructured porphyrins with extended auxiliary $\pi$-spacers for highly efficient dye-sensitized solar cells. ACS Appl Mater Interfaces 11(27):24067-24077. https://doi.org/10.1021/acsami.9b05510

10. Naik P, Elmorsy MR, Su R, Babu DD, el-Shafei A, Adhikari AV (2017) New carbazole based metal-free organic dyes with D-П-A$\Pi$-A architecture for DSSCs: synthesis, theoretical and cell performance studies. Sol Energy 153:600-610. https://doi.org/10.1016/j. solener.2017.05.088

11. Han ML, Zhu YZ, Liu S, Liu QL, Ye D, Wang B, Zheng JY (2018) The improved photovoltaic performance of phenothiazinedithienopyrrole based dyes with auxiliary acceptors. J Power Sources 387:117-125. https://doi.org/10.1016/j.jpowsour.2018.03. 059

12. Lima J, Andrade L, Pereira A et al (2017) Styryl and phenylethynyl based coumarin chromophores for dye sensitized solar cells. J Photochem Photobiol A Chem 353:564-569. https://doi.org/10. 1016/j.jphotochem.2017.12.018

13. Ohta N, Awasthi K, Okoshi K, Manseki K, Miura H, Inoue Y, Nakamura K, Kono H, Diau EWG (2016) Stark spectroscopy of absorption and emission of indoline sensitizers: a correlation with the performance of photovoltaic cells. J Phys Chem C 120(46): 26206-26216. https://doi.org/10.1021/acs.jpcc.6b08531

14. Chiykowski VA, Lam B, Du C, Berlinguette CP (2017) Comparative analysis of triarylamine and phenothiazine sensitizer donor units in dye-sensitized solar cells. Chem Commun 53(15): 2367-2370. https://doi.org/10.1039/c6cc09178d

15. Naik P, Su R, Elmorsy MR, el-Shafei A, Adhikari AV (2018) New carbazole based dyes as effective co-sensitizers for DSSCs sensitized with ruthenium (II) complex (NCSU-10). J Energy Chem 27(2):351-360. https://doi.org/10.1016/j.jechem.2017.12.013

16. Patil D, Jadhav M, Avhad K, Chowdhury TH, Islam A, Bedja I, Sekar N (2018) A new class of triphenylamine-based novel sensitizers for DSSCs: a comparative study of three different anchoring groups. New J Chem 42(14):11555-11564. https://doi.org/10. 1039/c8nj01029c

17. Suresh T, Chitumalla RK, Hai NT, Jang J, Lee TJ, Kim JH (2016) Impact of neutral and anion anchoring groups on the photovoltaic performance of triphenylamine sensitizers for dye-sensitized solar cells. RSC Adv 6(32):26559-26567. https://doi.org/10.1039/ c6ra00636a

18. Dong YX, Wang XL, Jin EM, Jeong SM, Jin B, Lee SH (2019) One-step hydrothermal synthesis of Ag decorated $\mathrm{TiO}_{2}$ nanoparticles for dye-sensitized solar cell application. Renew Energy 135: 1207-1212. https://doi.org/10.1016/j.renene.2018.12.062

19. Chang H, Chen CH, Kao MJ, Hsiao HH (2014) Effect of core-shell $\mathrm{Ag} @ \mathrm{TiO}_{2}$ volume ratio on characteristics of $\mathrm{TiO}_{2}$-based DSSCs. J Nanomater 2014:1-8. https://doi.org/10.1155/2014/264108

20. Gupta AK, Srivastava P, Bahadur L (2016) Improved performance of Ag-doped $\mathrm{TiO}_{2}$ synthesized by modified sol-gel method as photoanode of dye-sensitized solar cell. Appl Phys A Mater Sci Process 122(8):1-13. https://doi.org/10.1007/s00339-016-0241-2

21. Wu WY, Hsu CF, Wu MJ, Chen CN, Huang JJ (2017) Ag- $\mathrm{TiO}_{2}$ composite photoelectrode for dye-sensitized solar cell. Appl Phys A Mater Sci Process 123(5):1-8. https://doi.org/10.1007/s00339-0170963-9

22. Su'ait MS, Rahman MYA, Ahmad A (2015) Review on polymer electrolyte in dye-sensitized solar cells (DSSCs). Sol Energy 115: 452-470. https://doi.org/10.1016/j.solener.2015.02.043

23. Farhana NK, Ramesh S, Ramesh K (2019) Efficiency enhancement of dye-sensitized solar cell based gel polymer electrolytes using poly(vinyl butyral-co-vinyl alcohol-co-vinyl acetate)/ tetrapropylammonium iodide. Mater Sci Semicond Process 91: 414-421. https://doi.org/10.1016/j.mssp.2018.12.007

24. Ng HM, Ramesh S, Ramesh K (2015) Exploration on the P(VP-coVAc) copolymer based gel polymer electrolytes doped with quaternary ammonium iodide salt for DSSC applications: electrochemical behaviors and photovoltaic performances. Org Electron 22:132139. https://doi.org/10.1016/j.orgel.2015.03.020

25. Wu J, Lan Z, Lin J, Huang M, Huang Y, Fan L, Luo G, Lin Y, Xie Y, Wei Y (2017) Counter electrodes in dye-sensitized solar cells. Chem Soc Rev 46(19):5975-6023. https://doi.org/10.1039/ c6cs00752j

26. Huang C, Li C, Shi G (2012) Graphene based catalysts. Energy Environ Sci 5(10):8848-8868. https://doi.org/10.1039/c2ee22238h

27. Kannan AG, Zhao J, Jo SG, Kang YS, Kim DW (2014) Nitrogen and sulfur co-doped graphene counter electrodes with synergistically enhanced performance for dye-sensitized solar cells. J Mater Chem A 2(31):12232-12239. https://doi.org/10.1039/c4ta01927j

28. Gao Z, Wang L, Chang J, Liu X, Wu D, Xu F, Guo Y, Jiang K (2016) Nitrogen doped porous graphene as counter electrode for efficient dye sensitized solar cell. Electrochim Acta 188:441-449. https://doi.org/10.1016/j.electacta.2015.12.008

29. Yun S, Qin Y, Uhl AR, Vlachopoulos N, Yin M, Li D, Han X, Hagfeldt A (2018) New-generation integrated devices based on dye-sensitized and perovskite solar cells. Energy Environ Sci 11(3):476-526. https://doi.org/10.1039/c7ee03165c

30. Seery MK, George R, Floris P, Pillai SC (2007) Silver doped titanium dioxide nanomaterials for enhanced visible light photocatalysis. J Photochem Photobiol A Chem 189(2-3):258 263. https://doi.org/10.1016/j.jphotochem.2007.02.010

31. Gebreegziabher GG, Asemahegne AS, Ayele DW, Dhakshnamoorthy M, Kumar A (2019) One-step synthesis and characterization of reduced graphene oxide using chemical exfoliation method. Mater Today Chem 12:233-239. https://doi.org/10. 1016/j.mtchem.2019.02.003 
32. Pei K, Wu Y, Islam A, Zhang Q, Han L, Tian H, Zhu W (2013) Constructing high-efficiency D-A- $\pi$-A-featured solar cell sensitizers: a promising building block of 2,3-diphenylquinoxaline for antiaggregation and photostability. ACS Appl Mater Interfaces 5(11):4986-4995. https://doi.org/10.1021/am400754d

33. Lu X, Jia X, Wang ZS, Zhou G (2013) X-shaped organic dyes with a quinoxaline bridge for use in dye-sensitized solar cells. J Mater Chem A 1(34):9697-9706. https://doi.org/10.1039/c3ta11398a

34. Li SL, Jiang KJ, Shao KF, Yang LM (2006) Novel organic dyes for efficient dye-sensitized solar cells. Chem Commun 2(26):27922794. https://doi.org/10.1039/b603706b

35. Yang H, Yen Y, Hsu Y et al (2010) Organic dyes incorporating the dithieno[3,2-b:2',3'-d]thiophene moiety for efficient dye-sensitized solar cells. Org Lett 12(1):2008-2011. https://doi.org/10.1021/ ol902327p

36. Pannipara M, Asiri AM, Alamry KA, Arshad MN, el-Daly SA (2015) Synthesis, spectral behaviour and photophysics of donoracceptor kind of chalcones: excited state intramolecular charge transfer and fluorescence quenching studies. Spectrochim Acta A Mol Biomol Spectrosc 136:1893-1902. https://doi.org/10.1016/j. saa.2014.10.105

37. Al-Sehemi AG, Pannipara M, Kalam A, Asiri AM (2016) A combined experimental and computational investigation on spectroscopic and photophysical properties of a coumarinyl chalcone. J Fluoresc 26(4):1357-1365. https://doi.org/10.1007/s10895-0161823-2

38. Landis RF, Yazdani M, Creran B, Yu X, Nandwana V, Cooke G, Rotello VM (2014) Solvatochromic probes for detecting hydrogenbond-donating solvents. Chem Commun 50(35):4579-4581. https://doi.org/10.1039/c4cc00805g

39. Lokhande PKM, Sonigara KK, Jadhav MM, Patil DS, Soni SS, Sekar N (2019) Multi-dentate carbazole based Schiff base dyes with chlorovinylene group in spacer for dye-sensitized solar cells: a combined theoretical and experimental study. ChemistrySelect 4(14): 4044-4056. https://doi.org/10.1002/slct.201803940

40. Salimi Beni A, Zarandi M, Hosseinzadeh B, Najafi Chermahini A (2018) Density functional theory study of carbazole dyes: potential application of carbazole dyes in dye-sensitized solar cells. J Mol Struct 1164:155-163. https://doi.org/10.1016/j.molstruc.2018.02. 094

41. Santos LM, Machado WA, França MD, Borges KA, Paniago RM, Patrocinio AOT, Machado AEH (2015) Structural characterization of Ag-doped $\mathrm{TiO}_{2}$ with enhanced photocatalytic activity. RSC Adv 5(125):103752-103759. https://doi.org/10.1039/c5ra22647c

42. Wang F, Zhang S, Li C, Liu J, He S, Zhao Y, Yan H, Wei M, Evans DG, Duan X (2014) Catalytic behavior of supported Ru nanoparticles on the (101) and (001) facets of anatase $\mathrm{TiO}_{2}$. RSC Adv 4(21): 10834-10840. https://doi.org/10.1039/c3ra47076h

43. Ren R, Wen Z, Cui S, Hou Y, Guo X, Chen J (2015) Controllable synthesis and tunable photocatalytic properties of $\mathrm{Ti}^{3+}$-doped $\mathrm{TiO}_{2}$. Sci Rep 5(1):1-11. https://doi.org/10.1038/srep10714

44. Albiter E, Valenzuela MA, Alfaro S, Valverde-Aguilar G, Martínez-Pallares FM (2015) Photocatalytic deposition of Ag nanoparticles on $\mathrm{TiO}_{2}$ : metal precursor effect on the structural and photoactivity properties. J Saudi Chem Soc 19(5):563-573. https://doi.org/10.1016/j.jscs.2015.05.009

45. Suwarnkar MB, Dhabbe RS, Kadam AN, Garadkar KM (2014) Enhanced photocatalytic activity of $\mathrm{Ag}$ doped $\mathrm{TiO}_{2}$ nanoparticles synthesized by a microwave assisted method. Ceram Int 40(4): 5489-5496. https://doi.org/10.1016/j.ceramint.2013.10.137

46. Agyeman DA, Song K, Kang SH, Jo MR, Cho E, Kang YM (2015) An improved catalytic effect of nitrogen-doped $\mathrm{TiO}_{2}$ nanofibers for rechargeable $\mathrm{Li}-\mathrm{O}_{2}$ batteries; the role of oxidation states and vacancies on the surface. J Mater Chem A 3(45):22557-22563. https://doi.org/10.1039/c5ta05426e

47. Wang GF, Li MG, Gao YC, Fang B (2004) Amperometric sensor used for determination of thiocyanate with a silver nanoparticles modified electrode. Sensors 4(9):147-155. https://doi.org/10. 3390/s40900147

48. Chang G, Zhang J, Oyama M, Hirao K (2005) Silver-nanoparticleattached indium tin oxide surfaces fabricated by a seed-mediated growth approach. J Phys Chem B 109(3):1204-1209. https://doi. org/10.1021/jp046652h

49. Katsiaounis S, Panidi J, Koutselas I, Topoglidis E (2020) Fully reversible electrically induced photochromic-like behaviour of Ag: $\mathrm{TiO}_{2}$ thin films. Coatings 10(2):130. https://doi.org/10.3390/ coatings 10020130

50. Baran E, YazIcI B (2016) Effect of different nano-structured Ag doped $\mathrm{TiO}_{2}$-NTs fabricated by electrodeposition on the electrocatalytic hydrogen production. Int J Hydrog Energy 41(4):2498-2511. https://doi.org/10.1016/j.ijhydene.2015.12.028

51. Ran H, Fan J, Zhang X, Mao J, Shao G (2018) Enhanced performances of dye-sensitized solar cells based on $\mathrm{Au}-\mathrm{TiO}_{2}$ and $\mathrm{Ag}$ $\mathrm{TiO}_{2}$ plasmonic hybrid nanocomposites. Appl Surf Sci 430:415423. https://doi.org/10.1016/j.apsusc.2017.07.107

52. Sakthivel T, Kumar KA, Senthilselvan J, Jagannathan K (2018) Effect of Ni dopant in $\mathrm{TiO}_{2}$ matrix on its interfacial charge transportation and efficiency of DSSCs. J Mater Sci Mater Electron 29(3):2228-2235. https://doi.org/10.1007/s10854-017-8137-2

53. Feng X, Shankar K, Paulose M, Grimes CA (2009) Tantalumdoped titanium dioxide nanowire arrays for dye-sensitized solar cells with high open-circuit voltage. Angew Chem Int Ed 48(43): 8095-8098. https://doi.org/10.1002/anie.200903114

54. Shaikh SF, Mane RS, Joo OS (2015) $\mathrm{La}_{2} \mathrm{O}_{3}$-encapsulated $\mathrm{SnO}_{2}$ nanocrystallite-based photoanodes for enhanced DSSCs performance. Dalton Trans 44(7):3075-3081. https://doi.org/10.1039/ c4dt03564j

55. Zhang H, Lv Y, Guo Y, Tao X, Yang C, Zhou X (2018) Fully-air processed Al-doped $\mathrm{TiO}_{2}$ nanorods perovskite solar cell using commercial available carbon instead of hole transport materials and noble metal electrode. J Mater Sci Mater Electron 29(5):3759 3766. https://doi.org/10.1007/s10854-017-8310-7

56. Bandara TMWJ, Jayasundara WJMJSR, Dissanayake MAKL, Fernando HDNS, Furlani M, Albinsson I, Mellander BE (2014) Quasi solid state polymer electrolyte with binary iodide salts for photo-electrochemical solar cells. Int J Hydrog Energy 39(6):29973004. https://doi.org/10.1016/j.ijhydene.2013.05.163

57. Ravi M, Pavani Y, Kiran Kumar K, Bhavani S, Sharma AK, Narasimha Rao VVR (2011) Studies on electrical and dielectric properties of PVP: $\mathrm{KBrO}_{4}$ complexed polymer electrolyte films. Mater Chem Phys 130(1-2):442-448. https://doi.org/10.1016/j. matchemphys.2011.07.006

58. Raghu S, Kilarkaje S, Sanjeev G, Devendrappa H (2013) Electron beam induced modifications in conductivity and dielectric property of polymer electrolyte film. Radiat Meas 53-54:56-64. https://doi. org/10.1016/j.radmeas.2013.03.017

59. Ramesh S, Liew CW (2013) Dielectric and FTIR studies on blending of [XPMMA-(1 - X)PVC] with LiTFSI. Meas J Int Meas Confed 46(5):1650-1656. https://doi.org/10.1016/j.measurement.2013.01. 003

60. Tan CY, Farhana NK, Saidi NM, Ramesh S, Ramesh K (2018) Conductivity, dielectric studies and structural properties of P(VAco-PE) and its application in dye sensitized solar cell. Org Electron 56:116-124. https://doi.org/10.1016/j.orgel.2018.02.007

61. Zhang R, Zhang B, Sun S (2015) Preparation of high-quality graphene with a large-size by sonication-free liquid-phase 
exfoliation of graphite with a new mechanism. RSC Adv 5(56): 44783-44791. https://doi.org/10.1039/c5ra04480d

62. Senthilkumar R, Raj SM, Ramakrishnan S, Kumaresan D, Kothurkar NK (2018) Thermally reduced graphene oxide as a counter electrode material for dye-sensitized solar cells. J Nanosci Nanotechnol 19(4):2158-2165. https://doi.org/10.1166/jnn.2019. 16360

63. Johra FT, Lee JW, Jung WG (2014) Facile and safe graphene preparation on solution based platform. J Ind Eng Chem 20(5):28832887. https://doi.org/10.1016/j.jiec.2013.11.022

64. Muhammad Hafiz S, Ritikos R, Whitcher TJ, Md. Razib N, Bien DCS, Chanlek N, Nakajima H, Saisopa T, Songsiriritthigul P, Huang NM, Rahman SA (2014) A practical carbon dioxide gas sensor using room-temperature hydrogen plasma reduced graphene oxide. Sensors Actuators B Chem 193:692-700. https://doi.org/10. 1016/j.snb.2013.12.017

65. Rajaura RS, Srivastava S, Sharma V, Sharma PK, Lal C, Singh M, Palsania HS, Vijay YK (2016) Role of interlayer spacing and functional group on the hydrogen storage properties of graphene oxide and reduced graphene oxide. Int J Hydrog Energy 41(22):9454 9461. https://doi.org/10.1016/j.ijhydene.2016.04.115

66. Gui CX, Wang QQ, Hao SM, Qu J, Huang PP, Cao CY, Song WG, Yu ZZ (2014) Sandwichlike magnesium silicate/reduced graphene oxide nanocomposite for enhanced $\mathrm{Pb}^{2+}$ and methylene blue adsorption. ACS Appl Mater Interfaces 6(16):14653-14659. https:// doi.org/10.1021/am503997e

67. Wang R, Wang Y, Xu C, Sun J, Gao L (2013) Facile one-step hydrazine-assisted solvothermal synthesis of nitrogen-doped reduced graphene oxide: reduction effect and mechanisms. RSC Adv 3(4):1194-1200. https://doi.org/10.1039/c2ra21825a

68. Gurulakshmi M, Meenakshamma A, Susmitha K, Charanadhar N, Srikanth VVSS, Narendra Babu S, Venkata Subbaiah YP, Venkateswarlu K, Raghavender M (2019) A transparent and Ptfree all-carbon nanocomposite counter electrode catalyst for efficient dye sensitized solar cells. Sol Energy 193:568-575. https:// doi.org/10.1016/j.solener.2019.09.081

69. Sarkar A, Bera S, Chakraborty AK (2020) CoNi2S4-reduced graphene oxide nanohybrid: an excellent counter electrode for Ptfree DSSC. Sol Energy 208:139-149. https://doi.org/10.1016/j. solener.2020.07.075

70. Mary CI, Senthilkumar M, Manobalaji G, Babu SM (2020) Surface-treated $\mathrm{Cu} 2 \mathrm{ZnSnS} 4$ nanoflakes as Pt-free inexpensive and effective counter electrode in DSSC. J Mater Sci Mater Electron 31(20):18164-18174. https://doi.org/10.1007/s10854020-04365-9

71. Zhang C, Deng L, Zhang P et al (2017) Hydrothermal synthesis of NiS2 cubes with high performance as counter electrodes in dyesensitized solar cells. Int J Electrochem Sci 12:4610-4618. https:// doi.org/10.20964/2017.05.100

72. Silambarasan K, Archana J, Athithya S, Harish S, Sankar Ganesh R, Navaneethan M, Ponnusamy S, Muthamizhchelvan C, Hara K, Hayakawa Y (2020) Hierarchical NiO@NiS@graphene nanocomposite as a sustainable counter electrode for Pt free dye-sensitized solar cell. Appl Surf Sci 501:144010. https://doi.org/10.1016/j. apsusc. 2019.144010

73. Li S, Min H, Xu F, Tong L, Chen J, Zhu C, Sun L (2016) All electrochemical fabrication of $\mathrm{MoS}_{2} /$ graphene counter electrodes for efficient dye-sensitized solar cells. RSC Adv 6(41):3454634552. https://doi.org/10.1039/c6ra02494g

74. Chen M, Shao LL (2016) Review on the recent progress of carbon counter electrodes for dye-sensitized solar cells. Chem Eng J 304: 629-645. https://doi.org/10.1016/j.cej.2016.07.001

75. Hwang I, Yong K (2015) Counter electrodes for quantum-dotsensitized solar cells. ChemElectroChem 2(5):634-653. https:// doi.org/10.1002/celc.201402405

76. Mustafa MN, Shafie S, Zainal Z, Sulaiman Y (2017) A novel poly(3,4-ethylenedioxythiophene)-graphene oxide/titanium dioxide composites counter electrode for dye-sensitized solar cell. J Nanomater 2017:1-9. https://doi.org/10.1155/2017/4045672

77. Younas M, Gondal MA, Dastageer MA, Baig U (2019) Fabrication of cost effective and efficient dye sensitized solar cells with $\mathrm{WO}_{3}$ $\mathrm{TiO}_{2}$ nanocomposites as photoanode and MWCNT as Pt-free counter electrode. Ceram Int 45(1):936-947. https://doi.org/10.1016/j. ceramint.2018.09.269

78. Tian Z, Wang L, Jia L, Li Q, Song Q, Su S, Yang H (2013) A novel biomass coated $\mathrm{Ag}-\mathrm{TiO}_{2}$ composite as a photoanode for enhanced photocurrent in dye-sensitized solar cells. RSC Adv 3(18):63696376. https://doi.org/10.1039/c3ra40195b

79. Yeh MH, Lin LY, Chang LY, Leu YA, Cheng WY, Lin JJ, Ho KC (2014) Dye-sensitized solar cells with reduced graphene oxide as the counter electrode prepared by a green photothermal reduction process. ChemPhysChem 15(6):1175-1181. https://doi.org/10. 1002/cphc.201301128

80. Chiappara C, Figà V, Di Marco G et al (2016) Investigation of recovery mechanisms in dye sensitized solar cells. Sol Energy 127:56-66. https://doi.org/10.1016/j.solener.2016.01.010

81. Bramhankar TS, Pawar SS, Shaikh JS, Gunge VC, Beedri NI, Baviskar PK, Pathan HM, Patil PS, Kambale RC, Pawar RS (2020) Effect of nickel-zinc co-doped $\mathrm{TiO}_{2}$ blocking layer on performance of DSSCs. J Alloys Compd 817:152810. https://doi.org/ 10.1016/j.jallcom.2019.152810

82. Mehmood U, Ahmad SHA, Khan AUH, Qaiser AA (2018) Cosensitization of graphene $/ \mathrm{TiO}_{2}$ nanocomposite thin films with ruthenizer and metal free organic photosensitizers for improving the power conversion efficiency of dye-sensitized solar cells (DSSCs). Sol Energy 170:47-55. https://doi.org/10.1016/j.solener. 2018.05.051

83. Tan CY, Omar FS, Saidi NM, Farhana NK, Ramesh S, Ramesh K (2019) Optimization of poly(vinyl alcohol-co-ethylene)-based gel polymer electrolyte containing nickel phosphate nanoparticles for dye-sensitized solar cell application. Sol Energy 178:231-240. https://doi.org/10.1016/j.solener.2018.12.043

84. Yang Z, Li L, Luo Y, He R, Qiu L, Lin H, Peng H (2013) An integrated device for both photoelectric conversion and energy storage based on free-standing and aligned carbon nanotube film. J Mater Chem A 1(3):954-958. https://doi.org/10.1039/c2ta00113f

85. Dong P, Rodrigues MTF, Zhang J, Borges RS, Kalaga K, Reddy ALM, Silva GG, Ajayan PM, Lou J (2017) A flexible solar cell/ supercapacitor integrated energy device. Nano Energy 42:181-186. https://doi.org/10.1016/j.nanoen.2017.10.035

Publisher's note Springer Nature remains neutral with regard to jurisdictional claims in published maps and institutional affiliations. 